\title{
Professional Placement Service at 1967 Annual Meeting
}

\author{
(September 5-9, 1967)
}

A professional placement service will again be available to members of The American Political Science Association attending the Chicago meeting. The placement service will be provided by the U.S. Employment Service. The primary purpose is to provide an efficient means for employers to meet prospective employees and vice versa.

The Professional Placement Service is entirely separate from the APSA's Personnel Service and requires separate registration. There is no fee for use of the Professional Placement Service by employers or applicants at the Convention.

FOLLOW UP: Orders and applications will be returned to the local Employment Service Office after the Annual Meeting. The office will determine if a satisfactory placement occurred and, if not, will make further recruitment or replacement efforts.

All State Employment Service local offices accept orders and applications in the field of political science on a year-round basis as a regular part of their professional service.

If you plan to attend the Conference and utilize the Placement Service, please mail the form below as soon as possible, but not later than August 5, 1967. Application and/ or employer order forms will be forwarded to you upon receipt of the following information:

Name:

(Organization or Institution)

Address:

(City)

Employer

(check either)

$\square$ Prospective Candidate
(State)

No. of Vacancies

No. of Area(s) of Specialization

Fill in appropriate blocks and mail to: Mrs. Theresa Scholl, Professional Placement Center, Illinois State Employment Service, 208 South LaSalle Street, Chicago, Ill. 60604. 


\section{ASIAN TOUR-SEMINAR PROGRAM}

\section{9 countries-37 days-August 1-September 6}

Because of the success of past Tour-Seminar programs, the Association is offering another in its series of travel study opportunities during the summer of 1967, in Asia.

In addition to direct conversations with governmental leaders of the countries on the itinerary, Tour-Seminar participants will meet with members of the faculties of local universities, U.S. Foreign Service personnel, foreign press representatives, etc. Opportunity will be provided for a limited amount of personal research and sightseeing. The entire trip is being planned with the cooperation and support of the U.S. Department of State and the U.S. Information Service.

\section{TRANSPORTATION}

As was the case with the 1966 African Tour-Seminar, this program will be carried out on regularly scheduled jet flights of reputable international carriers.

The Asian Tour-Seminar is based on the group fare, requiring a minimum of 25 participants.

\section{EXPENSES}

The cost to Association members will be about $\$ 1645$ - substantially less than it would be for a similar trip arranged on an individual basis. Included in the fare will be round-trip tourist air transportation, first-class hotel accommodations, numerous meals, baggage handling, and airport transfers. (On the basis of past experience, participants can expect that the cost of this educational activity will be accepted as deductible expense on Federal tax returns.)

For further information concerning this unique educational, research, and travel opportunity, write immediately to: APSA 1967 Asian Tour-Seminar, The American Political Science Association, 1527 New Hampshire Avenue, N.W., Wasbington, D.C. 20036. A brocbure giving full details and reservation information will be mailed to you. 


\section{Notice \\ Resolutions \\ at \\ Annual Business Meeting}

In accordance with ARTICLE VIII of the Constitution, this is to call attention of members of the Association to the provision of the APSA constitution that:

"All resolutions shall be referred to the Council for its recommendations before submission to the vote of the Association at its Annual Business Meeting."

The Council of the Association will meet all day September 5, 1967 , in the Belmont Room, PickCongress Hotel, Chicago.

\section{COLUMBIA}

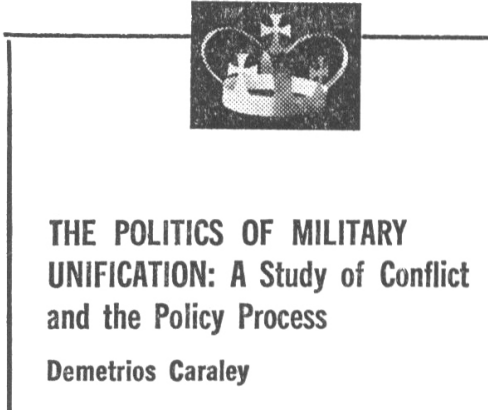

The proposal to unify the Departments of War and Navy and establish the post of Secretary of Defense provoked one of the most intense political conflicts of the entire post-World War II period. For four years it pitted high Army, Navy, Army Air, and Marine officers against each other, civilian officials against military, and the President against Congress. This study analyzes the unification conflict in terms of the actors involved, their goals and perceptions, and their strategies and tactics of influence. It provides fascinating details on the highpowered lobbying, public relations, and propaganda campaigns undertaken by the military services and serves also as an excellent case study of how conflict over policy develops and becomes resolved and what functions conflict serves in executive branch and congressional politics more generally.

"The author has done an outstanding job of research and putting the facts together in a most enjoyable and readable manner ... [R]equired reading for all persons involved in the U.S. defense establishment."-U. S. Naval Institute Proceedings.

$\$ 8.95$

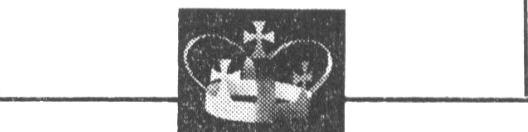

\section{COLUMBIA UNIVERSITY PRESS 440 West 110th Street \\ New York, N.Y. 10025}




\section{WORLD POLITICS}

\section{A Quarterly Journal of International Relations \\ JULY 1967}

On Approaches to the Study of International Relations, or Back to Machiavelli ...... David Vital

New Factors of Stability in Soviet Collective Leadership Jerome M. Gilison

Regional Organization and the Regulation of Internal Conflict Linda B. Miller

The Political Relation of the Village to the State Harumi Befu

Ideology and Politics in Economic Planning: The Problem of Indian Agricultural Development Strategy . Francine R. Frankel

Patterns of Representation in National Capitals and Intergovernmental Organizations ...... Chadwick F. Alger and Steven J. Brams

Review Articles by John K. Fairbank, Richard D. Challener, Fred Charles Ikle, and Nathan Leites. One Year $\$ 7.50$ - Two Years $\$ 12.50 \bullet$ Single Copies $\$ 2.50$

\section{CENTER OF INTERNATIONAL STUDIES}

Princeton University, Princeton, N. J. 08540

\section{Our Latest Publications:}

1. Agricultural Land use in Punjab: A Spatial Analysis by Gurdev Singh Gosal \& B. S. Ojha

Rs.15.00

2. Proceedings of the Conference on Administrative Reforms

Rs.10.00

3. Union Public Service Commission by M. A. Muttalib

Rs.13.00

Available from:

Administrative Officer

INDIAN INSTITUTE OF PUBLIC ADMINISTRATION

Indraprastha Estate

RING ROAD, NEW DELHI-1. 


\title{
THE INSTITUTE OF CONSTITUTIONAL AND PARLIAMENTARY STUDIES
}

\author{
18-Vithalbhai Patel House, Rafi Marg. New Delhi-1. (India)
}

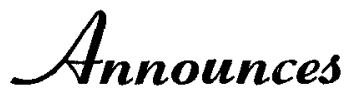

\section{the publication of a new quarterly \\ THE JOURNAL OF CONSTITUTIONAL AND PARLIAMENTARY STUDIES}

The Journal is devoted to studies in comparative constitutional law and problems and prospects of democratic governments in India and abroad. It is intended to serve as an independent forum of discussion in depth on problems of parliamentary procedures and legislative institutions. The basic object of the Journal as of the Institute sponsoring it is to disseminate democratic values and foster popular understanding of free institutions at different levels. The first issue of the Journal (January-March 1967) is already out and the second (April-June 1967) is in press.

Beyond a basic commitment to the philosophy of freedom and a faith in constitutional and representative government, the Journal itself does not hold or support any particular political ideology or party. Honest and critical contributions are welcome from scholars in India and abroad.

Regular features of the Journal include case comments, book-reviews, notes on current developments in the field of constitutional law and parliamentary affairs, a review of the parliamentary scene etc. Besides, articles are contributed by eminent parliamentarians, experienced civil servants, political scientists and constitutional and legal experts.

$$
\begin{array}{ll}
\text { Annual Subscription: } & \$ 5.50 \text { or } £ 2.00 \\
\text { Single copy: } & \$ 1.50 \text { or } 11 \mathrm{~s} .
\end{array}
$$

\section{EDITORIAL BOARD}
L. M. Singhvi, (Chairman)
S. L. Shakdher
N. C. Chatterjee, M.P.
B. N. Banerjee
M. C. Setalvad, M.P.
R. C. S. Sarkar
M. N. Kaul, M.P.
V. K. N. Menon

Editor

Subhash C. Kashyap

Joint Editor

D. C. Jain

Trade enquiries, subscriptions, manuscripts for publication, books for review and Journals for exchange may be addressed to the Editor. 


\section{THE FIRST VIETNAM CRISIS}

\section{MELVIN GURTOV}

"This book analyzes the political crisis of 1953-54, which resulted in the withdrawal of France from Indochina, the establishment of two Vietnams after the Geneva Convention, and the beginning of our multibillion-dollar commitment in the Vietnam war. ... . This is an amply documented book which provides necessary background to the Vietnam conflict and some insight into the complexities of political decision-making. Recommended."-Library Journal

\section{THE CHINESE COMMUNIST ARMY IN ACTION}

The Korean War and lts Aftermath

\section{ALEXANDER L. GEORGE}

This remarkable account, based on a series of interviews with selected Chinese Communist prisoners of war, examines the political and military organization of the Chinese Communist People's Liberation Army. The author deals with the organization of the Army in Korea as revealed by the prisoners, details the effect of the encounter with UN Forces on the Chinese Communist military organization, and concludes with an analysis of developments in the PLA since the Korean War.

\section{CADRES, BUREAUCRACY, AND POLITICAL POWER IN COMMUNIST CHINA}

\section{A. DOAK BARNETT, with a contribution by EZRA VOGEL}

A comprehensive study of the organization and operation of the political system in Communist China. Based in large part on intensive interviews with Chinese emigrees who formerly worked for the Party or government in mainland China, it presents detailed information on political and governmental structure from the central government in Peking to the local communes. The author analyzes the manner in which the Communists' political apparatus now reaches and affects the mass of ordinary Chinese, and reveals many political trends and problems which will preoccupy Communist China's leaders in the years ahead.

\section{COLUMBIA UNIVERSITY PRESS}

2960 Broadway

Now York, N. Y, 10027

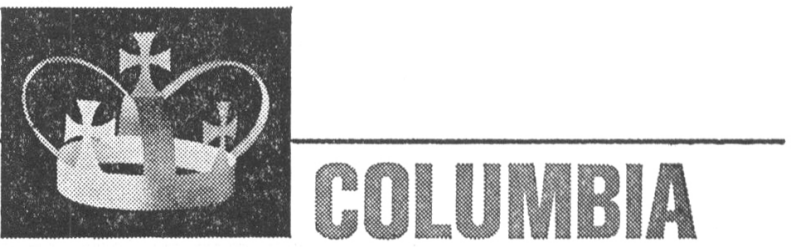

Please mention The American Political Scinnce Revirw when writing to advertisers 
PATHS TO WORLD ORDER

ANDREW W. CORDIER and KENNETH MAXWELL, Editors

The seven essays in this book are concerned with the need for a common ethic in international affairs. The theological implications in the search for an underlying ethic that will lead to world order, and the chief menace to world order, the difference between the "have" and "have not" nations, are among the subjects covered.

Paper, $\$ 1.75$

\section{NATO AND THE RANGE OF AMERICAN CHOICE \\ WILLIAM T. R. FOX and ANNETTE BAKER FOX}

A study of the works of NATO over the past fifteen years. The authors deal not only with decisions involving national security and Soviet military threats but also with the basic problems of arms control, international cooperation for an expanded economy, and the relation of NATO to the needs of developing countries.

$\$ 7.95$

\section{THE UN SECRETARY-GENERAL AND THE MAINTENANCE OF PEACE LEON GORDENKER}

In tracing the techniques employed by the three Secretaries-General of the United Nations in maintaining or restoring peace in the major crises in which the UN has been involved, Professor Gordenker is able to derive conclusions regarding the limitations of the office as it is now constituted, and the possibilities for its expansion of influence in the future.

$\$ 8.50$

\section{COLUMBIA ESSAYS IN INTERNATIONAL AFFAIRS \\ Volume II The Dean's Papers, 1966 \\ ANDREW W. CORDIER, Editor}

The second annual volume of essays written by students of the Columbia University faculty of International Affairs. Topics treated include: The Gaullist Challenge; French Policy and Supranationality; The Birth of Communism in Southeast Asia; and Local Government and Politics in China: 1955-1958.
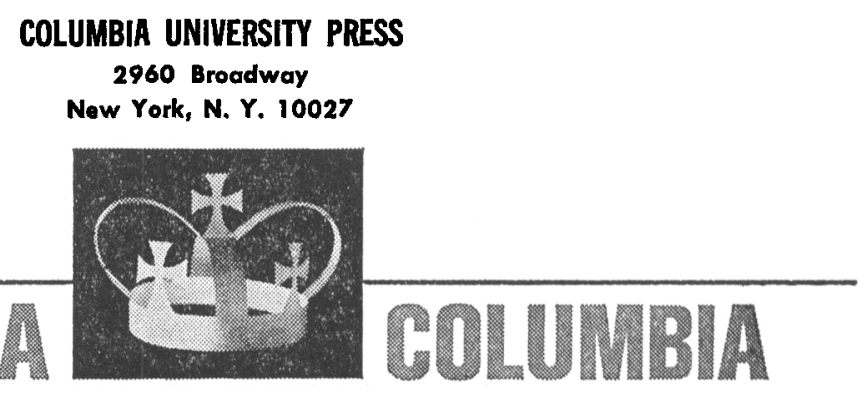

Please mention The Amaricas Polirical Screxce Rrview when writing to advertisers 


\section{Nazi Germany and the American Hemisphere, 1933-1941}

by Alton Frye

Through his examination of Nazi activities in the Americas and of the evidence from captured German archives, Alton Frye concludes that National Socialist Germany posed a distinct threat to the Western hemisphere. Among the book's most disturbing disclosures is the defailed review of Germany's clandestine interference in the American presidential campaign of 1940.

$\$ 6.75$

\section{The Indus Rivers}

\section{A Study of the Effects of Partition}

by Aloys A. Michel

This study analyzes the profound effects which the Partition of the Punjab has had on the regional economy and organization of the subcontinental portion of the Indus Basin. Mr. Michel assesses projects underway in India and West Pakistan since Partition, and also the engineering techniques being employed to restore the efficiency of the old, integrated irrigation system.

$\$ 12.50$

\section{Soviet Political Schools}

\section{The Communist Party Adult Instruction System}

by Ellen Propper Mickiewicz

Virfually unknown to the West, Soviet adult political education has undergone enormous expansion in the last decade. By 1964, thirty-six million people were enrolled in the system. This study is the first, by either a Western or Soviet scholar, to assess the strengths and weaknesses of the system devoted to the "political tempering" of adults.

$\$ 6.50$

\section{The Origins of Malay Nationalism}

\section{by William R. Roff}

The slow growth of communal, ethnic, and national feeling among the peninsular Malays during the first four decades of this century, and the expression of this feeling in voluntary associations of a potentially nationalist nature are the subjects of Mr. Roff's study. He points to three new Malay elite groups as offering an implicit challenge to the traditional status quo in the interests of a distinctly Malay nationalism.

$\$ \mathbf{8 . 5 0}$

\section{available through your bookstore \\ Yale University Press Y A \\ New Haven and London $\mathrm{L}$ \\ in Canada: McGill University Press}




\section{Tibet: A Political History}

by Tsepon W. D. Shakabpa

with a Foreword by His Holiness the Dalai Lama

In 1959 the Dalai Lama of Tibet, disguised as a peasant and accompanied by a small band of supporters, escaped the threatening Chinese Communist regime and took refuge in India. Among those living in exile is W. D. Shakabpa, former Minister of Finance, who has now written the first history of Tibet by a Tibetan to be published in English.

August $\$ 10.00$

\section{Yale Paperbounds}

\section{Children and Politics}

\section{by Fred I. Greenstein}

"The uniqueness of Greenstein's effort is that it is the first book-length empirical treatment of the political socialization of American elementary school children."-American Political Science Review.

$\$ 1.75$ (cloth \$5.00)

\section{Arms and Influence}

by Thomas $C$. Schelling

"An exemplary text on the inferplay of national purpose and military force."-Book Week. "A brilliant and hardheaded book."-New York Times. \$1.95 (cloth \$7.50)

\section{Village in Vietnam}

\section{by Gerald Cannon Hickey}

"Mr. Hickey's report has great value for its penetration to realities of the Vietnamese sitwation."-New York Times. "Of major importance."-Book Week.

$\$ 2.95$ (cloth \$10.00)

\section{The Lawmakers}

Recruitment and Adaptation to Legislative Life

by James David Barber

"Clearly one of the most significant studies of American politics written since the advent of behavioral studies in political science."-Western Political Quarterly.

$\$ 1.95$ (cloth \$7.50)

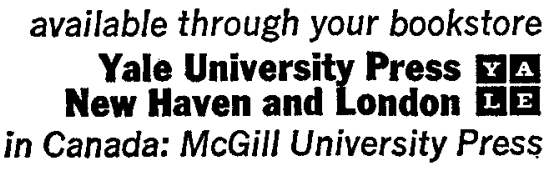




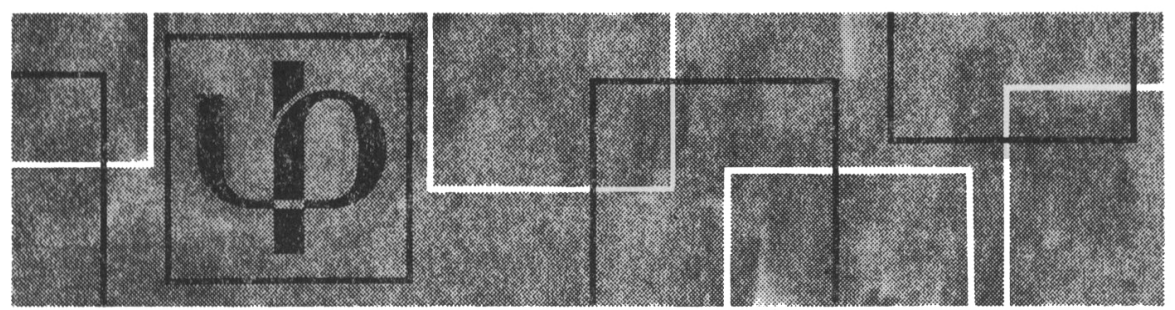

\section{AS WE SAW THE THIRTIES}

\section{Essays on Social and Political Movements of a Decade}

by Norman Thomas, Earl Browder, Max Shachtman, Gerald L. K. Smith, A. J. Muste, Granville Hicks, Hal Draper, and Burton K. Wheeler

edited by Rita Simon

Here are first-person, eye-witness accounts of major movements of the thirties, written by the men who led them. From the turbulent chronicle of American radicalism to the impact of the New Deal, the most formative political decade of the century is reexamined in terms of purposes, goals, and actual achievements. 253 pages. $\$ 6.50$.

\section{NEW FRONTIERS OF THE AMERICAN RECONSTRUCTION} edited by Harold M. Hyman

Traditional views of the Civil War and Reconstruction are challenged and revised in these essays which focus on the period through four differing approaches: constitutional history, political history, Negro Reconstruction, and the effects of the period on Latin America and Canada. Contributors to the volume are Harold M. Hyman, Alfred H. Kelly, John Hope Franklin, August Meier, Harry Bernstein, W. L. Morton, C. Vann Woodward, and Russel B. Nye. 156 pages. $\$ 4.95$.

\section{IMPROVING THE STATE LEGISLATURE}

\section{Report of the Illinois Commission on the Organization of the General Assembly}

This pioneering study in an area of increasing national concern details the findings and specific proposals of a state commission created by the Illinois General Assembly in 1965 , to examine ways and means of modernizing and improving the legislative process. Evolved from joint research by the commission and consulting specialists in political science and government, these findings explore a wide range of problems critical to modern state government, including constitutional impacts on the legislative process, general legislative procedures and techniques, the potential of committees and commissions, and the appropriation process. 146 pages. Paper, $\$ 2.95$; cloth, $\$ 4.95$.

\section{LAW IN THE SOVIET SOCIETY}

\section{edited by Wayne R. LaFave}

Legal scholars, political scientists, economists, and others will find valuable information and new frames of reference in these seven essays dealing with various aspects of the role of law in Soviet socio-political development and international relations. Contributors are Demitri B. Shimkin, Dennis M. O'Connor, Bernard A. Ramundo, Dietrich A. Loeber, Whitmore Gray, Zigurds L. Zile, and John N. Hazard. "This is a usefully informative book, and its appearance in paperback is welcome." - The Russian Review. ". . . a major contribution to American scholarship of Soviet administrative, civil, and criminal law." - Choice. 297 pages. Paper, \$1.95; cloth, \$4.75.
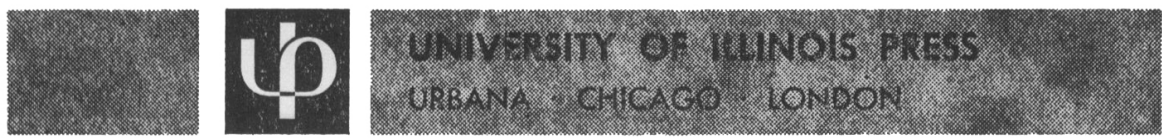

Please mention Thr Amgrican Political Scimacr Review when writing to advertisers 


\title{
From ST. MARTIN'S
}

Just published:

\author{
Parliament, Parties and \\ Society in France, 1946-1958 \\ Duncan MacRae, Jr., The Univ. of Chicago
}

This important new book is a case study in political sociology. It includes an analysis of voting in the National Assembly in relation to party structure, constituency voting behavior, and social structure. The author has based his analysis on more than 800 legislative roll-call votes processed by computer, survey and aggregate voting data, and the relation of this information to constituencies, party structure, and legislative careers. To provide background he has used newspaper accounts of the Assembly and sociological analysis of the French social structure. The findings reveal two contrasting political subsystems: consensus in the Assembly and dissensus and protest outside. $1967 \quad 416$ pp. $\$ 10.00$

\section{The Modern Presidency \\ Grant McConnell, The Univ. of Chicago}

This fourth book in St. Martin's Series in American Politics is a coherent exposition of the modern presidency as it has emerged through the long term of American historyespecially as it has been transformed in the years since the Depression. $1967128 \mathrm{pp}$. Paper: $\$ 1.50$

\section{Influencing Voters \\ A Study in Campaign Rationality \\ Richard Rose, Univ. of Strathclyde}

During an election campaign, dozens of individuals concentrate intensively upon spending millions of dollars to influence voters. Do their efforts corrupt our conventional version of the liberal process? Do party leaders and pressure group heads show themselves ready to use any method possible to sway votes? Are the methods employed effective? The author here sets out to answer these questions by carefully examining campaigning in Britain in 1959 and 1964. He has included material on American experience and the 1966 British campaign as well to demonstrate the many obstacles to rationality in efforts to influence voters. 1967292 pp. $\$ 5.95$

\section{Fall publication:}

\section{The New Urbanization in New Nations and Old}

Editors: Scott Greer and David W. Minar, Northwestern Univ.; Dennis C. McElrath, Univ. of California, Santa Cruz; and Peter Orleans, U.C.L.A.

Fall $1967 \$ 8.50$ tent.

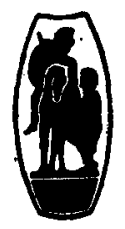

$$
\begin{aligned}
& \text { Co } 11 \text { e } g \text { e e p a } \mathbf{m} \text { e } \mathbf{t} \\
& \text { S T. M A R T I N S P R E S S } \\
& 175 \text { Fifth Avenue, New York, N.Y. } 10010
\end{aligned}
$$

Please mention The Amkricas Politicar. Science Rzview when writing to advertisers 


\section{Cornell University Press}

\section{MAJOR THEMES-}

\section{Russian Political Thought}

\section{An Introduction}

By THORNTON ANDERSON. In this lucid and fully documented appraisal of Russian political theory and practice, the author stresses the coritinuity as well as the evolution of ideas. He examines the present Soviet regime, not simply in terms of its Marxist-Leninist concepts, but as a development of traditional Russian political assumptions. He shows how Orthodoxy, Mongol invasions, the fall of Byzantium, and even attempts at Westernization under Peter and Catherine led to the present isolation of Russia from the West.

432 pages. $\$ 9.75$

\section{Comparative Political Development}

\section{The Precedent of the West}

By G. LOWELL FIELD. A bold reclassification of political systems here forms the basis for new comparisons among governmental regimes. Using rigorous scientific and logical methods to classify types of political units, the author constructs a systems model and applies it to explain existing policies and to predict future change. Usual distinctions - such as that between democracy and dictatorship disappear, and new delineations that are both accurate and objective suggest new approaches to current problems. 8 diagrams, 6 tables.

288 pages. $\$ 6.75$

\section{The Politics of Futility}

The General Jewish Workers Bund of Poland, 1917-1943

By BERNARD $\mathrm{K}$. JOHNPOLL. Largely from the Bund's own archives, most of which escaped destruction, Professor Johnpoll has put together this study of a movement that survived until its constituency had been literally wiped out. His moving account, with dramatic sidelights on Zionism, Soviet Communism, and the Polish resistance, adds a revealing chapter in the history of the Jews and of the Socialist movement.

314 pages. $\$ 8.75$ 


\section{PROVOCATIVE IDEAS}

\section{International Communism in the Era of Lenin}

Edited and with commentary by HELMUT GRUBER. This documentary history of international communism provides a concise and stimulating narrative framework into which the most significant doctrinal statements, manifestoes, analyses, and tactical decisions have been interwoven. The documentary material itself highlights the events of the Lenin era and, together with the narrative and a select number of interpretive essays, illuminates the growth of national communist parties against the background of the developing Communist International. 512 pages. $\$ 7.50$

\section{Political Parties in Lebanon}

\section{The Challenge of a Fragmented Political Culture}

By MICHAEL SULEIMAN. The role of political parties in a "confessional democracy" like Lebanon's demonstrates the function and limitations of parties in many emerging nations. In this pioneering study, Professor Suleiman examines the parties on their own terms - as political guides and critics in a highly sectarian society. The nineteen parties, including two Moslem religious groups, are categorized as legal or illegal, national or transnational, pan-Arab or sectarian, and their history, organization, platforms, and ideology are carefully examined in the context of Lebanese political tradition.

336 pages. $\$ 7.50$

\section{Religion, Politics, and Diversity}

The Church-State Theme in New York History

By JOHN WEBB PRATT. In this first history of church-state relations in a major state, the author details the conflicts and the evolution of a system of compromise in New York from colonial times to the present. He recommends that all concerned with church-state issues view the record to learn how our pluralistic society can continue to adjust its differences in light of today's shifting balance between local and federal power.

336 pages. $\$ 7.50$

\section{Cornell University Press}

ITHACA, NEW YORK 14850 


\section{THE COLUMBIA RIVER TREATY}

\section{The Economics of an Infernational River Basin Development}

BY JOHN V. KRUTILLA

In September, 1964, the U.S. and Canada ratifled the Columbia River Treaty, which provided for a joint financing and development of the Columbia River Basin, with special reference to electrical power and flood control. This study attempts to determine what was the basis for the selection of projects, how closely this basis reflected economic realities, and how the division of benefits affected each party to the treaty. Part I contains a theoretical discussion of international river development; Parls II and III apply these general criteria to the Columbia River experience.

\section{THE ORSANCO STORY}

Water Quality Management in the Ohio Valley under an

Inferstate Compact

\section{BY EDWARD J. CLEARY}

One of the most successful efforts to control water pollution was inaugurated in 1948 by eight states-Illinois, Indiana, Kentucky, New York, Ohio, Pennsylvania, Virginia, and West Virginia-who signed a compact to coordinate their resources for a regional assault on mutual problems of stream pollution. The principal focus was on the 981 -mile Ohio River and its nineteen major tributaries, which flow through the member states. This study is an account of why and how the pioneering ORSANCO compact came into being, what it achieved, and what may be learned from its experience in cleaning up a river basin.

$\$ 8.00$ cloth, $\$ 2.95$ paper

\section{THE JOHNS HOPKINS PRESS}

Baltimore, Maryland 21218

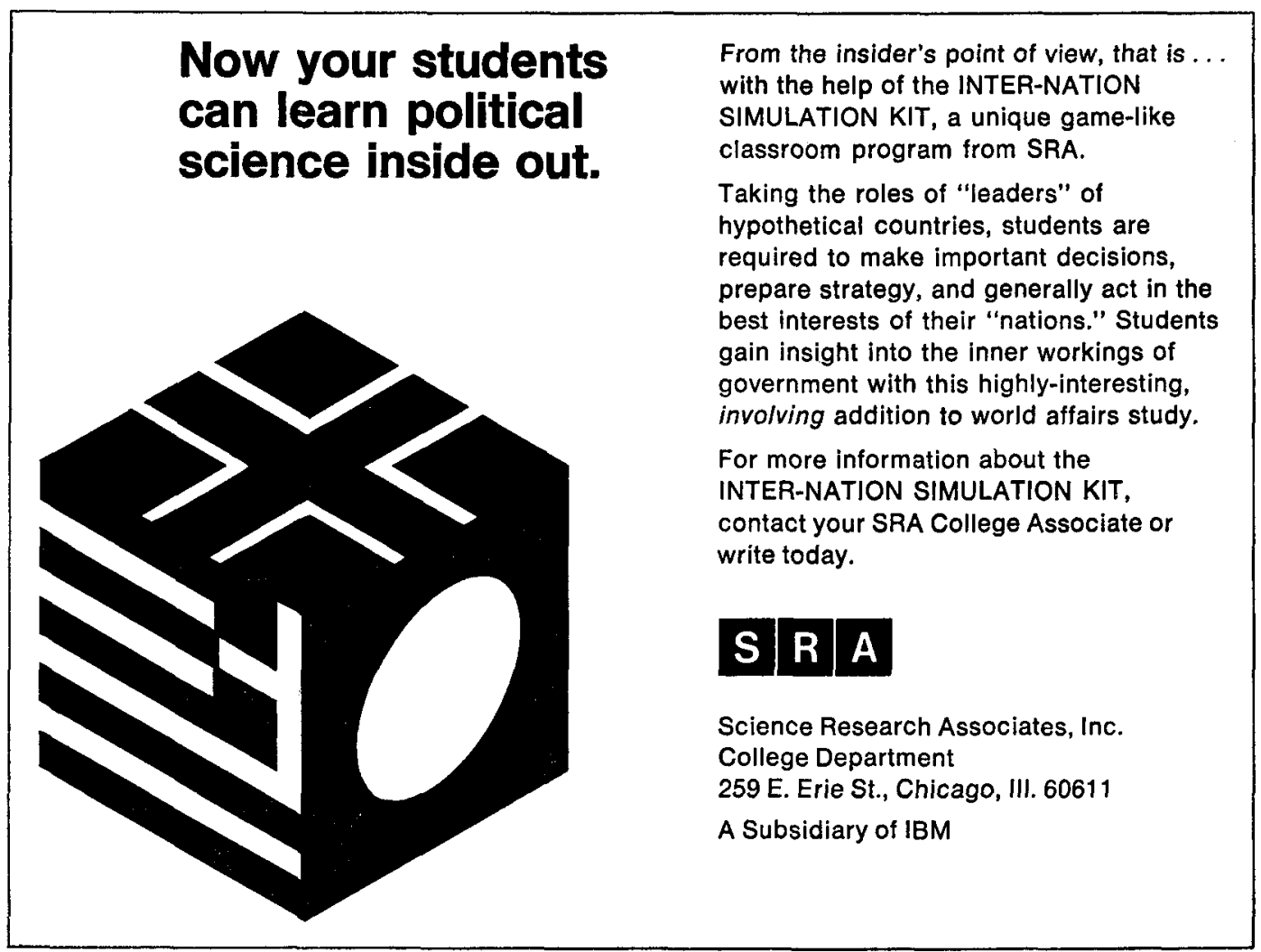

Please mention Thr American Political Scirnce Revizw when writing to advettisers 


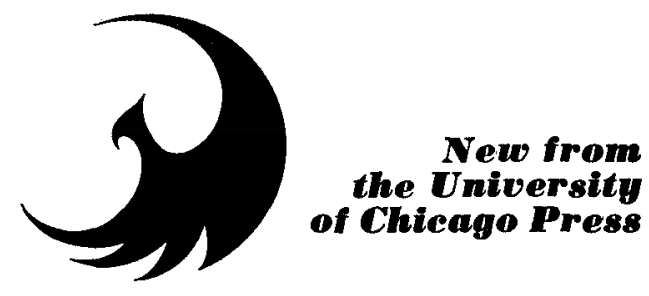

Modern Factor Analysis

Revised Edition

Harry H. Harman
Economic Development and Ameriean Foreign Poliey $1943-62$

David A. Baldwin

Some sections have been condensed and others have been expanded to bring the book into accord with modern usage. Other changes are: A new chapter on Minres Method of factor analysis and a new section on the Direct Oblimin Method of transformation to oblique factors; consistent use of matrix notation in accordance with the usage of mathematical statisticians; computer applications; new problems and exercises; and an updated bibliography. Harry H. Harman is senior research psychologist, Educational Testing Service, Princeton.

1967 LC:67-20572 480 pages, $\$ 12.50$

Tracing the evolution of American foreign policy in an increasingly competitive field, Baldwin stresses the bargaining aspects of the relations between the executive branch and Congress and between the executive and foreign governments. He focuses on soft lending as the government's most important aid technique, and his conclusion sharply challenges several views concerning the constructive roles of the International Bank and Congress in promoting economic development and making foreign policy.

1966 LC:66-20597 291 pages, $\$ 7.95$

The First Emancipation

The Abolition of

Negro Slavery in the North

Arthur Zilversmit
This description of the social and economic role slavery played in the North traces the movement that led to its gradual abolition. Ideology, Zilversmit argues, and not lack of profitability, brought about the first emancipation. Early attacks on slavery by the Quakers combined with the libertarian principles of the Revolution helped the abolitionists persuade state legislators that, in this issue, concern for property rights could be tempered for the sake of individual liberty.

1967 LC:67-15954 353 pages, $\$ 6.95$
The Death of Slavery

The United States, 1837-65

Elbert B. Smith
This fast-paced account of the crucial pre-Civil War period completes the chronological series of the "Chicago History of American Civilization." Smith's first-hand knowledge of politics gives the work an unusual emphasis which is especially appropriate for the politics of the times. "Chicago History of American Civilization" series, Daniel J. Boorstin, General Editor.

1967 LC:67-16779 232 pages, $\$ 5.00$ 


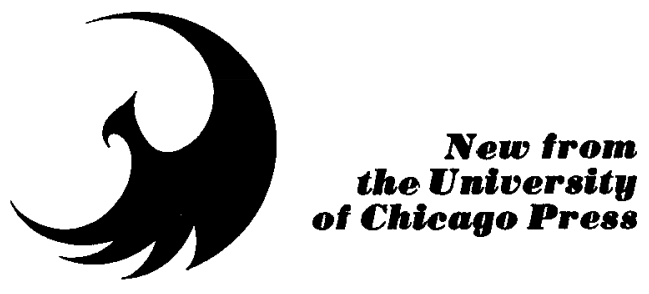

The Court and the Constitution

$A$ series edited by Philip B. Kurland
This new paperback series brings back into print in modestly priced editions a number of important books on past Supreme Court Justices and on the role of the Court in American life. As well as filling a need for students of law, political science, government, and history, these volumes will provide, collectively, a history of the Supreme Court.

Melville Weston Fuller presided over the Supreme Court for twenty-two terms-a period in which the Court handed down such important decisions as those on the Income Tax Cases of 1895 , the "original-package doctrine," the Insular Cases, and the now discredited "separate but equal" doctrine of Plessy v. Ferguson. In his new Introduction to this biography Phil $\mathrm{C}$. Neal writes, "Fuller emerges in these pages as, among other things, an attractive human being. . . . Our understanding of a major era of the Supreme Court is the richer for this work."

1967416 pages Paper $\$ 2.95$

\section{The Unpublished Opinions of Mr. Justice Brandeis}

The Supreme Court at Work

Alexander M. Bickel

With an Introduction by Paul A. Freund
From 1916 to 1939 Louis Dembitz Brandeis opposed the tendency of a majority on the Supreme Court to cling to a "laissezfaire" conservatism. Both without and within the Court, he exerted enormous influence in shaping the social and economic thought of the nation. This book gives the reader a rare opportunity to explore the mind of one of America's greatest jurists. Dean Acheson, in commending Professor Bickel's "excellent book," notes: "For the lawyer who wants a full-length view of Justice Brandeis' judicial methodology it is indispensable."

1967320 pages Paper $\$ 2.45$
John Marshall

James Bradley Thayer

With a Foreword by Mark De Wolfe Howe
First published in 1901, this concise biography remains an eminently readable introduction to the great Chief Justice. Thayer demonstrates that Marshall's most enduring contribution to the nation's welfare lay in his "strong constitutional doctrine, explained in detail, elaborated, powerfully argued, over and over again, with unsurpassable earnestness and force, placed permanently in our judicial records, holding its own during the long emergence of a feebler political theory, and showing itself in all its majesty when war and civil dissension came."

1967196 pages

Paper $\$ 1.95$ 
The Papers of James Madison

Volume $V$

1 August 1782

-31 December 1782

Edited by

William T. Hutchinson and William M. E. Rachal
These 200 documents include Madison's notes on Congressional debates beginning in November, 1782, and focus upon the many domestic and foreign problems facing the government during the last five months of that year. The ominous discontent of civilian and military creditors of the Confederation, and the threatening manifestations of sectional rivalries are portrayed in illuminating detail. Reviewers of previous volumes have said: "This edition of the Madison Papers is a massive contribution of scholarship and a fitting monument to one of America's most notable philosopher-statesmen."-Jacob E. Cooke, Pennsylvania History. "The editing is magnificent as we are accustomed to expect."-Times Literary Supplement.

1967 LC:62.9114 496 pages, $\$ 12.50$
The Corresponalence of Edmumd Burke

Volume VI

July 1789.December 1791

Edited by

Alfred Cobban and Robert A. Smith

Volume VI of Burke's correspondence (July 1789-December 1791) covers the beginning of the French Revolution. Of the 225 letters reproduced here, 164 were written in whole or in part by Burke. Many are of major political importance. The correspondence of these years is an essential supplement to Burke's other writings, for some of his attitudes toward the Revolution, which he saw as a turning-point in Western civilization, he revealed only in private letters.

1967 LC:58.5615 495 pages, $\$ 13.50$

The

Supreme Court Review 1966

Edited by

Philip B. Kurland

Contents: Felix Frankfurter: A Lesson of Faith, Archibald MacLeish-The Obscenity Cases: Grapes of Roth, C. Peter Magrath -The Voting Rights Cases, Alexander M. Bickel-Albertson v. S.A.C.B.: The Conflict between the Privilege against Self-Incrimination and the Government's Need for Information, John $H$. Mansfield-Kent v. United States: The Constitutional Context of Juvenile Cases, Monrad G. Paulsen-Elfbrandt v. Russell: The End of the Era of the Oath?, Jerold H. Israel-The Union as Litigant: Personality, Pre-emption, and Propaganda, Alfred Kamin-Graham v. John Deere Co.: New Standards for Patents, Edmund W. Kitch-The Origins of Franklin D. Roosevelt's Court-packing Plan, William E. Leuchtenburg.

1966 LC:60-14353 400 pages, $\$ 8.95$

The Growth of American Comstitutional Law

Benjamin F. Wright

With an Introduction by Robert G. McCloskey
This brilliant survey evaluates the work of the Supreme Court up to the early 1940 's, when the two great issues of modern constitutional history-the decline of laissez-faire and the rise of civil rights-were just taking shape. In his new introduction Robert G. McCloskey describes Wright as embodying "a deep knowledge of the institutional and intellectual history of America; a political scientist's concern to understand the Court as an operative instrument of government; and a respect for the judicial ideal of rationality and a sharply critical eye for the Court's shortcomings in its pursuit of that ideal."

1967296 pages $P$ aper $\$ 2.45$ 


\section{RECOMMENDED bY VAN NOSTRAND ...}

THE SOVIET CRUCIBLE, The Soviet System in Theory and Practice, Third Edition

Edited with introductory notes by Samuel Hendel, The City College of the City University of New York. Available Fall 1967, approximately 600 pages, about \$4.95 (paper).

The achievements, failures and prospects of Soviet society are examined in this collection of writings. The author has combined original source material by the men who have helped shape the Soviet system. Commentary is by the following disfinguished observers of the Soviet scene: George F. Kennan, Sidney Hook, Harrison Salisbury, Robert W. Campbell, Isaac Deutscher, and Bertram D. Wolfe. The new contributions to this expanded and updated Third Edition include: the nature and prospects of socialist democracy; the Russians as people; the effect of politics on Sovief law, the new economic plan, 1966-1970, the search for economic rationality and economic growth; and the impact of Marxist theory of Soviel practice.

\section{THE VAN NOSTRAND}

\section{POLITICAL SCIENCE SERIES}

Franklin L. Burdette, General Editor

\section{STATE AND LOCAL GOVERNMENT,}

\section{Second Edition}

By Russell W. Maddox, Jr. and Robert F. Fuquay, both of Oregon State University. 1966, 736 pages, $\$ 8.50$.

This revised Second Edition sets forth the basic principles, institutions, and functions of American government at the state and local levels. The text is designed for a one-semester undergraduate course in State and Local Government.

\section{ISSUES IN STATE AND LOCAL GOVERNMENT: Selected Readings}

Edited by Russell W. Maddox, Jr. 1965, 424 pages, $\$ 4.75$ (paper).

This collection of readings has been designed specifically for basic college and university courses in State and Local Government and as a supplement for American Government courses. The selections have been divided into ten parts: The States in the Federal System, State Constitutions,

\section{Send for your on-approval copies. Write College Department,}

State Executives, State Legislatures, Law and the Courts, Political Processes, Finance and Personnel, Local Governmenls, Metropolitan Areas, Programs and Policies.

\section{EUROPEAN POLITICAL INSTITUTIONS:}

\section{A Comparative Government Reader,}

\section{Second Edition}

Edifed by William G. Andrews, Tufts University. 1966,608 pages, $\$ 4.95$ (paper).

This compilation represents a new concept in studies of comparative political institutions: it focuses upon the political institutions of the United Kingdom, France, Germany, and the Soviet Union, as viewed by the leaders of each country.

\section{SOVIET INSTITUTIONS AND POLICIES: Inside Views}

Ediled by William G. Andrews. 1966, 424 pages, $\$ 4.50$ (paper)

Each of the fifty-six articles in this book are from original sources and provide new perspective on some facet of the Soviel system. Differing markedly from the descriplive-interpretive viewpoints of conventional books, these selected readings provide more vivid insights into the nature of Russia's conflict with the West.

\section{CIVIL LIBERTIES IN AMERICA}

By Esther C. Sweet, Tufts University. 1966, 368 pages, $\$ 3.95$ (paper).

Suitable as a basic casebook for Civil Liberties courses or as a supplement for Constitutional and American Government courses, this book provides the student with a basic knowledge of specific areas in the field of civil liberties and acquaints him with some of the deeply rooted conflicts that have given rise to the various cases.

\section{EUROPEAN POLITICS I:}

\section{The Restless Search}

Edited by William G. Andrews. Contributors: Carl J. Friedrich; Anthony S. King; William G. Andrews, Stanley Hoffman; Elmer Plischke; and Samuel Hendel. 1965, 245 pages, $\$ 2.50$.

Van Nostrand Comparative Government Biennial

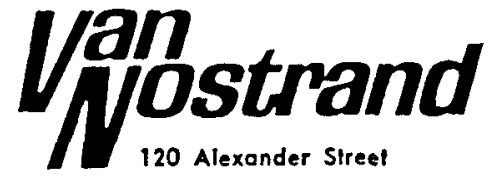

Princeton, New Jersey 08540 


\section{Outstanding Political Science Texts from the Dorsey Press}

\section{THE LANGUAGE OF MODERN POLITICS:}

\section{An Introduction to the Study of Government}

By H. MARK ROELOFS, New York University. This book presents to the beginning student the view that politics should be studied for what it is-a distinctly human activity in which men attempt to converse about and communicate their problems. About 400 pages. May. Text price: $\$ 7.50$.

\section{THE NATURE OF POLITICAL INQUIRY}

By FRED M. FROHOCK, Syracuse University. This book defines political inquiry through a discussion of the necessary role of theory in investigation. About 200 pages. July.

\section{CONTEMPORARY POLITICAL THOUGHT: A Critical Study}

By EUGENE J. MEEHAN, Brandeis University. A critical, analytical study, this book examines discussion now taking place about methodological, conceptual, and evaluative problems in the study of politics. 449 pages. June.

\section{PATTERNS OF SOVIET POLITICS, Revised Edition}

By RICHARD C. GRIPP, San Diego State College. Expanded and reorganized, this new edition provides new information on such developments as Khrushchev's downfall and the new five-year plan. About 650 pages. July.

\section{THE ELEMENTS OF INTERNATIONAL LAW, Revised Edition}

By GERARD J. MANGONE, Syracuse University. Greatly expanded and completely updated, this new Revised Edition presents additional introductory text material for each section of cases and documents. 551 pages. Text price: $\$ 8.50$.

\section{THE AMERICAN POLITICAL SYSTEM: Notes and Readings}

Edited by BERNARD E. BROWN, Brooklyn College of the City University of New York, and JOHN C. WAHLKE, The University of Iowa. Systematic, analytic, and dynamic, this book places the study of the American political system in the same perspective as the study of politics in general. 682 pages. Paperbound. Text price: $\$ 4.75$.

\section{CONGRESS AND FOREIGN POLICY-MAKING:}

\section{A Study in Legislative Influence and Initiative, Revised Edition}

By JAMES A. ROBINSON, The Ohio State University. With current information and more extensive analyses, more than one third of this book has been' rewritten from new material. 266 pages. May. Paperbound.

Published in THE DORSEY SERIES IN POLITICAL SCIENCE Consulting Editor: NORTON E. LONG, Brandeis University

Wrife Today for Examination Copies

THE DORSEY PRESS • HOMEWOOD, ILLINOIS

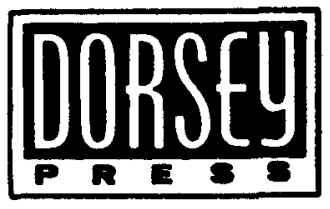




\section{LOOKING FOR A BOOK PUBLISHER?}

It is no secret that publication is regarded as the foundation stone of a scholar's career. In order to gain recognition, prestige, and advancement, the scholar must seek publication.

Here at Exposition Press, we offer scholars a complete publishing service, under our special academic imprint, "Exposition-University Books." Though the proportion of scholarly publications in the lists of the trade houses is shrinking, due to economic pressures, many of our recent titles in the academic fields have gained popular reviews, professional recognition and steady sales. These books are the result of a publishing plan that is bringing a steady flow of scholarly writers to Exposition Press. They reflect the high editorial standards and quality of design and production which have won the respect of libraries, schools, booksellers and critics. Ask for free catalogs.

FREE! The behind-the-scenes story of book publishing revealed in two fact-filled, illustrated brochures, containing a detailed description for our subsidy plan including a breakdown of contract terms and typical costs (in print for the first time). Copies are available on request. Your inquiries and manuscripts are invited. An editorial appraisal will be furnished promptly without obligation. References upon request.

\section{Please write to Dept. 93F}

EXPOSITION PRESS, Main Office, 386 Park Ave. So., New York 16, N.Y. California office: 9172 Sunset Blvd., Los Angeles 69, Calif.

\section{Be an esotericist}

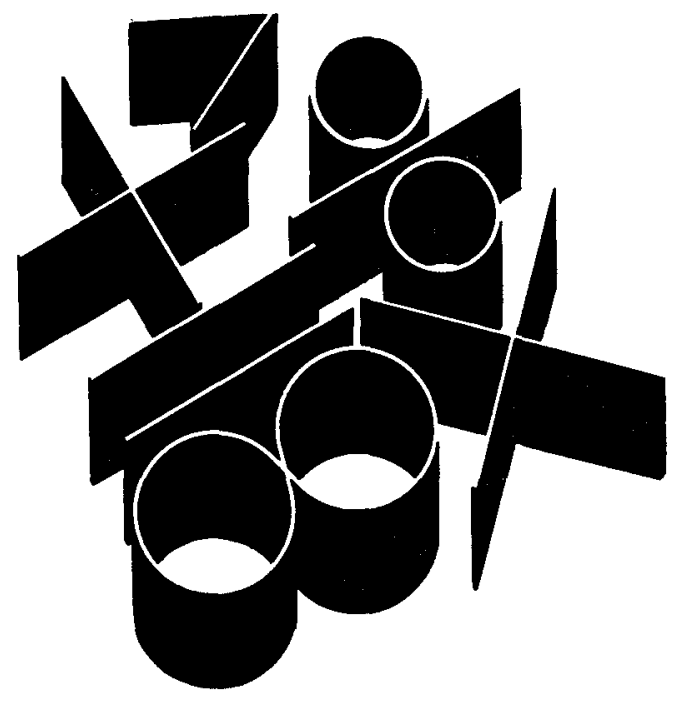

Join the select few who are looking into mathematical social science. Readings in Mathematical Social Science contains 18 papers and is the first published volume to apply mathematics to a variety of disciplines in the social sciences.

Edited by Paul F. Lazarsfeld, Quetelet Professor of Social Science, Columbia University and Neil W. Henry, Bureau of Applied Research, Columbia University. Hardbound. Price: $\$ 10.50$

For your copy, contact your SRA College Associate or write.

\section{S $\mathbf{R}$ A}

Science Research Associates, Inc. College Department 259 E. Erie St., Chicago, III. 60611

A Subsidiary of IBM 


\section{Oxford University Press}

\section{Constitutionalism and the Separation of Powers}

By M. J. C. VILE, Nuffield College, University of Oxford. "Freedom ordains rules. Government is lost liberty." This is the paradox which this book explores and which has confronted theorists of constitutional government since earliest times. Mr. Vile traces the history of the doctrine of separation of powers from its birth during the English Civil War through its development in the eighteenth century-including its significance in the American and French Revolutions and in subsequent constitution-making - to its place in political thought in Britain, France, and America in the nineteenth and twentieth centuries.

\section{Britain and the Rise of Communist China A STUDY OF BRITISH ATTITUDES 1945-1954}

By BRIAN E. PORTER, University College, Aberystwyth, Wales. This study focuses on British attitudes, as they are reflected in government, policy, parliamentary debate, and public opinion, towards the emergence of Communist China as a great power. There is also a record of the issues, wars, and problems which accompanied the rise of Red China. Dr. Porter believes that Western responses helped to produce a series of crises which have convulsed the Far East and heightened world tension.

$\$ 5.60$

\section{Freedom and Unity-Uhuru na Umoja A SELECTION FROM WRITINGS AND SPEECHES 1952-1965}

By JULIUS K. NYERERE, President of Tanzania. This selection covers the years of the growth of TANU, the campaign for national freedom and the beginning of Tanganyika, and then Tanzania as an independent nation. The papers reflect President Nyerere's role in and concern for the politics of his country, and the education and welfare of Tanzania's citizens. 15 balftones.

$\$ 7.20$

\section{The Principles of Politics}

By J. R. LUCAS, Merton College, Oxford. In his book, Mr. Lucas stresses the importance of thinking out afresh the principles of our own politics. He bases his arguments on the limitations of men: incomplete unselfishness, fallible judgment, and imperfect information, pointing out that institutions should counteract these imperfections. The nature of political argument and political obligation is discussed, and the traditional ideas of natural law and the rules of law, of legality, equality, freedom, and justice are elucidated and reformulated in modern terms.

$\$ 8.00$

\section{OXFORD UNIVERSITY PRESS}

200 Madison Avenue, New York, N.Y. 10016 


\section{Oxford University Press}

\section{The Power Structure \\ POLITICAL PROCESS IN AMERICAN SOCIETY}

By ARNOLD M. ROSE, University of Minnesota. This revealing survey of the American political process investigates the central question: who holds political power in the United States and how is this power used? The author, who disputes the views of C. Wright Mills, examines the many different groups exerting political pressure and the ways they achieve varying results under varying circumstances.

Cloth, \$8.50. A Galaxy Book, GB 194, paper, \$2.95

\section{An Encore for Reform THE OLD PROGRESSIVES AND THE NEW DEAL}

By OTIS L. GRAHAM, JR., University of California, Sansa Barbara. The author delves into an important source of the reform tradition - the reformers of the Progressive era who survived into the days of the New Deal. Through interviews with over 100 of them, he discovered that more than half opposed the New Deal in whole or in part. "I have read it with interest and admiration. This is a fine monograph."-FRANK FREIDRL, Harvard University.

\section{The Puritan Ethic and Woman Suffrage}

By ALAN P. GRIMES, Michigan State University. The woman suffrage movement in America has usually been seen as a progressive force; this book reveals another, generally ignored, side of the movement. Professor Grimes shows how it actually became a major weapon in the hands of the nativist forces that were organizing against the large blocs of foreign immigrants. "One of the few studies of women and woman suffrage which advance beyond guesswork and anecdote to real historical analysis."-C CHRISTOPHER LASCH, Northwestern University.

$\$ 4.75$

\section{Acquaintances}

By ARNOLD J. TOYNBEE. Twenty-four people or couples who made an impression on Dr. Toynbee are described by him. The characters include public figures such as Nehru, Smuts, and T. E. Lawrence, whom he merely met, but in interesting circumstances. Close personal friends and relations are portrayed with affection and admiration and in an entertaining manner. This book sheds new light on a number of well-known people, and a very warm light indeed on its author. 12 plates.

$\$ 7.50$

OXFORD UNIVERSITY PRESS

200 Madison Avenue, New York, N.Y. 10016

Please mention The American Political Science Review when writing to advertisers 


\section{Oxford University Press}

\section{Elites In Latin America}

Edited by SEYMOUR MARTIN LIPSET, Harvard University; and ALDO SOLARI. Essays by fifteen social scientists from the United States and Latin America analyze the groups that control the society, politics and economy of Latin America. The problems of development and modernization, as reflected in the elites, are discussed in detail-with special emphasis on the ways in which the educational systems affect the competence, orientation, and the composition of future elites.

Clotb, \$9.50. A Galaxy Book, GB 192, paper, \$2.95

\section{Politics in Brazil 1930-1964 AN EXPERIMENT IN DEMOCRACY}

$B y$ THOMAS E. SKIDMORE, University of Wisconsin. This book examines whether the 1964 breakdown of constitutional processes in Brazil was inevitable. It is a thorough study of Brazilian politics, beginning with Getulio Vargas's fifteen-year rule. The author shows a keen awareness of how the difficulties of economic expansion, an unfavorable trade balance, inequitable land distribution, and shifting political power have hindered Brazil's growth and stability in this classic study of a nation in the throes of industrialization.

$\$ 8.75$

\section{The Politics of the Third World}

By J. D. B. MILLER, Australian National University. The author's view is that there is no necessary harmony to views within the Third World except on issues of symbolic importance-and even there, the degree of harmony is likely to lessen in the future. In supporting his position he analyzes the consequences of Afro-Asian nationalism; examines such bodies as OAU and the Arab League; looks at the Bandung and Algiers attempts to project an Afro-Asian point of view; and evaluates the efforts of the major powers to increase their influence. (Royal Institute of International Affairs.)

Cloth, $\$ 3.75$, paper, $\$ 1.50$

\section{Stalin}

\section{A POLITICAL BIOGRAPHY, SECOND EDITION}

By ISAAC DEUTSCHER. This masterly work, first published in 1949, is firmly established as the standard life of Stalin and one of the most notable political biographies of our time. The major importance of this edition is the new, extensive closing chapter on Stalin's last years. Besides discussing the forces that shaped Stalin's life, this study is devoted to his foreign policy and its relation to Soviet Russia's internal evolution.

Cloth, \$12.50. A Galaxy Book, GB 195, paper, $\$ 2.95$

\section{OXFORD UNIVERSITY PRESS}

200 Madison Avenue, New York, N.Y. 10016 


\section{Institutions in Modern America}

\section{Innovation in Structure and Process \\ Edited by STEPHEN E. AMBROSE}

Each of these essays-which were first delivered in the spring of 1966 as the James Schouler Lectures at The Johns Hopkins University under the sponsorship of the Center for the Study of Recent American History-attempts to analyze one aspect of the extraordinary organizational developments that have characterized the first sixfy-five years of the present century. Professors Chandler, Ropp, and Brody discuss the corporation, the military establishment, and the labor union, respectively, and find organizational structure to be of prime importance; Professor Leuchtenburg finds process to be more important than structure in his analysis of politics. But all agree that great changes have come, and that they have come in the form of a pragmatic response to daily needs.

\section{Modern Yemen, 1918-1966}

\section{BY MANFRED W. WENNER}

This is the story of the power vacuum that followed Yemeni independence in 1918 and the events that led up to the establishment of the Yemeni republic in 1962. Professor Wenner places the policies of the Imams Yahya and Ahmad in the context of Yemeni development and shows how the Yemeni rulers attempted to exploit European conflicts for their own ends. Throughout the study he sets U.S.-Yemeni relations against the background of postWorld War II international politics, and concludes with an analysis of the civil war which began in 1962.

\section{Canada's Changing Defense Policy, 1957-1963}

The Problems of a Middle Power in Alliance

By JON B. MCLIN

This is a study of several controversial issues in Canadian defense and Canadian-American relations, including Canada's participation in NORAD, its purchase of several advanced aircraft, and the decision to acquire nuclear weapons. In reconstructing and interpreting these events, Dr. McLin finds that much of the problem stemmed from a lack of clarity about Canada's purposes in alliance participation, which in its case serves ends that are more political than military. The events of this period are examined in the perspective of Canadian defense policy since 1945; the policy changes that were made after the Pearson Government replaced that of John Diefenbaker in 1963 are also described.

THE JOHNS HOPKINS PRESS

Baltimore, Maryland 21218 


\section{PAPERBACKS for fall classes}

\section{THE SOVIET UNION: An Introduction}

\section{George Alexander Lensen, The Florida State University}

Drawing on the intimate knowledge gained through extended residence in the U.S.S.R., Dr. Lensen provides a vivid picture of Russian life and culture, including in his presentation basic political, historical, geographic, and economic information on the Soviet state.

September 1967128 pages 30 photographs by the author

\section{WORLD TENSIONS: Conflict and Accommodation}

Elton Atwater, Kent Forster, and Jan S. Prybyla, all of The Pennsylvania State University

A basic introduction to world affairs, this is a lucid treatment of the principal sources of-and various means of resolving - international tension and conflict. It carefully examines the economic, social, political, and ideological determinants of nations' behavior. Instructor's manual now in preparation.

June 1967400 pages illustrated

\section{A SECOND FEDERALIST: Congress Creafes a Government}

Edited by Charles S. Hyneman, Indiana University; and George W. Carey, Georgetown University

A presentation of congressional debates from 1789 to 1824 , abridged and excerpted from the Annals of Congress, the most complete account of what was said and done by Congress in its first four decades.

\section{January 1967325 pages $\$ 2.95$}

\section{THE SUPREME COURT AND FUNDAMENTAL FREEDOMS, 2nd Ed.} GEORGE W. SPICER, University of Virginia

The long-awaited revision of Spicer's brief, incisive, critical analysis of the Supreme Court as a guardian of American civil liberties.

February 1967280 pages $\$ 2.45$

\section{SOURCES IN MODERN EAST ASIAN HISTORY AND POLITICS}

Edited by THEodore McNelly, University of Maryland

Source materials and readings on the recent history, politics, ideologies, and international relations of China, Japan, Korea, and Vietnam, designed to supplement, and correlated with, standard textbooks.

$$
\text { May } 1967416 \text { pages illustrated }
$$

\section{CASES IN CONSTITUTIONAL LAW, 1964-1966}

Robert F. Cushman, New York University

\section{December 196673 pages $\$ .95$}

(A second supplement, Cases in Constitutional Law, 1966-1967, will be available for fall classes.)

\section{Appleton-Century-Crofts




\section{Important New Books From Macmillan}

\section{FORGING WORLD ORDER:}

\section{The Politics of International Organization}

By Jack C. Plano, Western Michigan University, and Robert E. Riggs, University of Minnesota

An analytical survey of the theory and history of contemporary international institutions is presented in this important new book. Emphasizing the concepts of influence and power, the authors examine the historical development of international cooperation. All types of world organizations are then discussed, with major emphasis placed on political processes and the actual functioning and interacting of the various groups. Many pedagogical aids are included.

1967, 600 pages, $\$ 8.95$

\section{THE UNITED NATIONS:}

\section{International Organization and Administration}

Edited by Maurice Waters, Wayne State University

This valuable collection contains readings, sources, speeches, and documents relating to all phases of the United Nations. Giving both the historical development and the theory of international organization, the material is structured to show both the external and internal features of the U.N.

1967, 583 pages, paper, $\$ 4.95$

\section{THE FUNCTIONING OF THE INTERNATIONAL SYSTEM}

By Andrew M. Scott, The University of North Carolina

The first book to apply a general systems approach to the study of international relations, this book consists of a set of interrelated propositions that build on one another as the book progresses. Both facts and assumptions are stated clearly. Making considerable use of communications theory, problems of perception theory, and conflict analysis, the author provides an integrated approach to international relations.

1967,228 pages, prob. $\$ 2.95$

\section{POLITICS, ECONOMICS, AND POWER: Ideology and}

\section{Practice Under Capitalism, Socialism, Communism, and Fascism}

By Nathaniel Stone Preston, The American University

". . . A real contribution to the teaching literature, for both comparative government and comparative economic systems courses..."

-Professor Michael D. Reagan, University of California, Riverside

This well-written book begins by providing a brief history of the development of political and economic forces in Western Civilization. Then each of the four major ideologies is examined in terms of its objectives, operating principles, and actual practice. The relevance of each system to developing nations is also discussed. The final chapter makes some observations on the future of the various systems.

1967, 242 pages, paper, $\$ 2.95$

Write to the Faculty Service Desk for examination copies.

\section{THE MACMILLAN COMPANY}

866 Third Avenue, New York, New York 10022

Please mention The American Political Scrence Review when writing to advertisers 


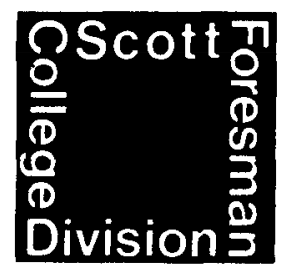

\section{Ready in August}

\section{THE CITIZEN AND THE ADMINISTRATOR IN A DEVELOPING DEMOCRACY}

\section{An Empirical Study in Delhi State, India}

\section{S. J. ELDERSVELD, The University of Michigan}

V. JAGANNADHAM, The Indian Institute of Public Administration, New Delhi, India A. P. BARNABAS, The Indian Institute of Public Administration, New Delhi, India

Utilizing survey data to test basic theoretical propositions about the developing Indian democracy, this book deals with various aspects of the Indian bureaucracy, both as it was inherited from the British and as it has been influenced by current social and political attitudes. The authors' pilot study of citizen perception of and contacts with five administrative agencies, together with a study of administrators' role perception and behavior, is based on over 600 interviews with a random sample of citizens in urban and rural areas and over 200 interviews with a random sample of administrators. The results of this study are frequently compared with the results of a similar study in Detroit, Michigan.

The book begins with an introductory theoretical chapter, moves through a presentation of basic data on the public's evaluations of and responses to the agencies and their administrators, and describes the administrators' social and professional backgrounds, job concepts, and performance. It also highlights the importance of the quality and quantity of bureaucratic contacts, focusing especially on public involvement with the Community Development and various agricultural projects. A final chapter summarizes the meaning of this analysis for the problems, prospects, and paradoxes of administration in the Indian democracy.

THE CITIZEN AND THE ADMINISTRATOR IN A DEVELOPING DEMOCRACY can serve as primary reference material for political science courses in comparative politics and administration as well as for those dealing with political development in south Asia. Especially useful to the reader is an appendix which includes the sample design and the questionnaires used.

160 pages prob. $\$ 6.00$

\section{SCOTT, FORESMAN AND COMPANY College Division}
Glenview, Illinois
Aflanta Dallas
Palo Alto
Oakland, N.J. 

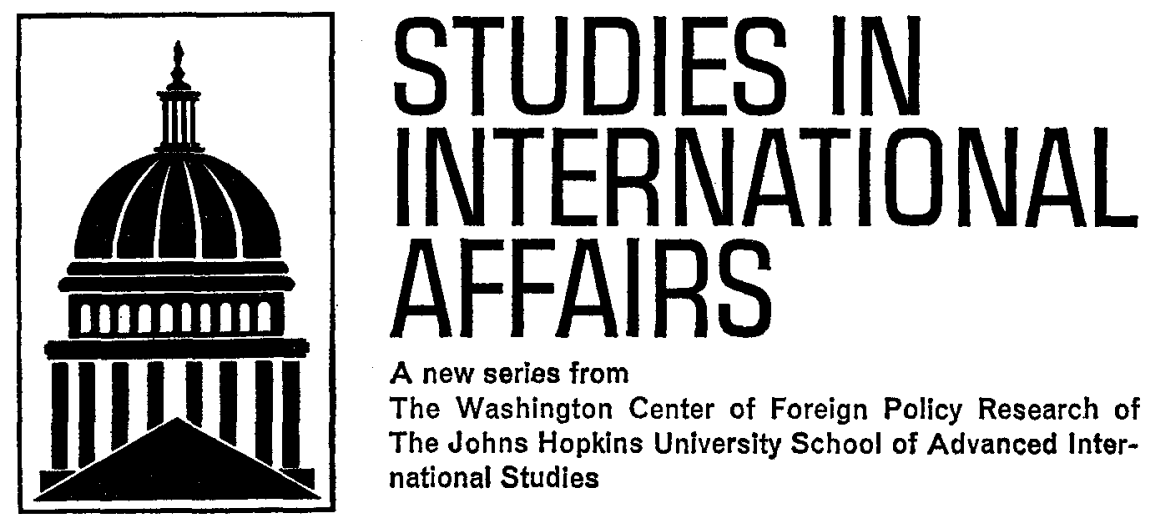

A new series from

The Washington Center of Foreign Policy Research of The Johns Hopkins University School of Advanced International Studies

The four studies listed below are the first in a series of booklet publications on international political and economic affairs. Between four and six studies will be published each year. These publications will reflect the Center's major continuing interests: the examination of trends in international politics and the assessment of America's evolving foreign policy. They will analyze and comment on issues of current interest to policy makers, the academic community, and informed persons generally.

\section{Studies in International Affairs}

\section{INTERVENTION AGAINST COMMUNISM}

By Herbert S. Dinerstein

Proposes guidelines for U.S. intervention against communism based on a historical analysis of past experiences, including Vietnam and the Dominican Republic.

$\$ 1.45$

\section{IMPERIAL AMERICA: THE INTERNATIONAL POLITICS OF PRIMACY \\ By George Liska}

Examines the exercise of America's pre-eminent power and influence in relation to salient trends in International politics, with special emphasis on the implication of these trends for U.S. foreign policy.

$\$ 2.25$

\section{CRISIS DVER RHODESIA: A SKEPTICAL VIEW}

\section{By Charles Burton Marshall}

Examines the background and development of the Rhodesian question and demonstrates that most of the public debate, in the U.N. and elsewhere, has been ill-informed and unrealistic.

"This work of careful scholarship and lively writing makes easy the duty of every member of Congress, every editor, every citizen who feels obligation to keep track of what his Government is up to."-Dean Acheson

\section{THE CHANGING STATUS OF GERMAN REUNIFICATION IN WESTERN DIPLOMACY, 1955-1986}

By Charles R. Planck

Reviews the course of NATO policy on German reunification from the perspective of Bonn's efforts to have its preferences respected in regard to such questions as a final European settlement, disarmament, and priorities in the search for East-West détente. 


\section{MARX'S ECONOMIC PREDICTIONS}

by Fred $M$. Gottheil

During the course of his creative years (1843-83), Marx produced a large quantity of economic, political, and historical books, essays, pamphlets, addresses, and correspondence. Dispersed among these writings were many prophecies, both abstract and specific. Marx's Economic Predictions evaluates over 150 of his predictions as logical derivatives of his theoretical system.

$$
x v+216 \text { pages }
$$

\section{SOUTH AFRICA'S TRANSKEI}

The Politics of Domestic Colonialism

\section{by Gwendolen Carter, Thomas Karis, and Newell M. Stultz}

The Transkei, a large tribal reserve situated in the eastern Cape Province, was established by the South African government as its first semiautonomous territory. In this book, the authors describe, analyze, and evaluate the program of "separate development" as demonstrated in the Transkei experiment. Northwestern University African Studies, Number Nineteen.

$$
192 \text { pages } \$ 5.50
$$

\section{PERSPECTIVES ON THE COURT}

\section{by Max Freedman, William M. Beaney, and Eugene V. Rostow}

During the past twenty years the Supreme Court has been involved in reformulating our fundamental law as it relates to civil rights, separation of church and state, reapportionment, and criminal procedures. Here, the Court's performance is viewed by three eminent men from the vantage points of journalism, political science, and law.

$$
120 \text { pages } \$ 3.50
$$

\section{APPROACHES TO COMPARATIVE AND INTERNATIONAL POLITICS}

\section{R. Barry Farrell, editor}

In this volume, twelve internationally respected political scientists analyze the relationship between national and international politics. These scholars are Karl W. Deutsch, James N. Rosenau, Carl J. Friedrich, George I. Blanksten, Pablo González Casanova, Norton E. Long, R. Barry Farrell, Vernon V. Aspaturian, Roland Young, Chadwick F. Alger, Raoul Naroll, and Oliver Benson.

$$
368 \text { pages cloth, } \$ 9.95 \text { paper, } \$ 3.95
$$

\section{NORTHWESTERN UNIVERSITY PRESS}

Evanston, Illinois 

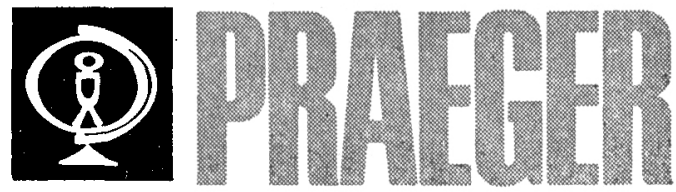

\section{Outstanding new paperback texts in political science}

THE IDEOLOGIES OF THE DEVELOPING NATIONS

Revised Edition
HOW NATIONS NEGOTIATE
Edited with an Introduction by PAUL E. SIGMUND. Foreword by Reinhold Niebuhr. Through selections from articles, speeches, and books, Professor Sigmund surveys the political thought and ideologies of the leaders of the developing nations in Asia, Africa, the Middle East, and Latin America. An extensively revised and expanded edition of the now-standard text which Africa Today has called "a penetrating analysis of personalities and parties." ca. 440 pp. U-529/ $\$ 2.95$

By FRED CHARLES IKLE. Now to be made available in a Praeger paperback edition-the groundbreaking study of the science of negotiation written under the auspices of Harvard's Center for International Affairs and first published in 1964. "An attempt to codify negotiating behavior and to construct an operational code. . . . A fresh attack on a neglected field of inquiry."-PROFESSOR WILLIAM T. R. FOX, in Science. 286 pp. U-630/\$2.50

By H. V. WISEMAN. An ideal text for political sociology, comparative systems, and introductory political science courses: Professor Wiseman summarizes the sociological approaches that have afforded new insights into the study of political systems, relating the theories of Talcott Parsons, Max Weber, and Seymour Lipset to those of Gabriel Almond, David Apter, Edward Shils, and others. 254 pp. bibliog., index. U-629/ $\$ 2.25$

\section{FREDERICK A. PRAEGer, Publishers}

111 Fourth Avenue, New York, N.Y. 10003 


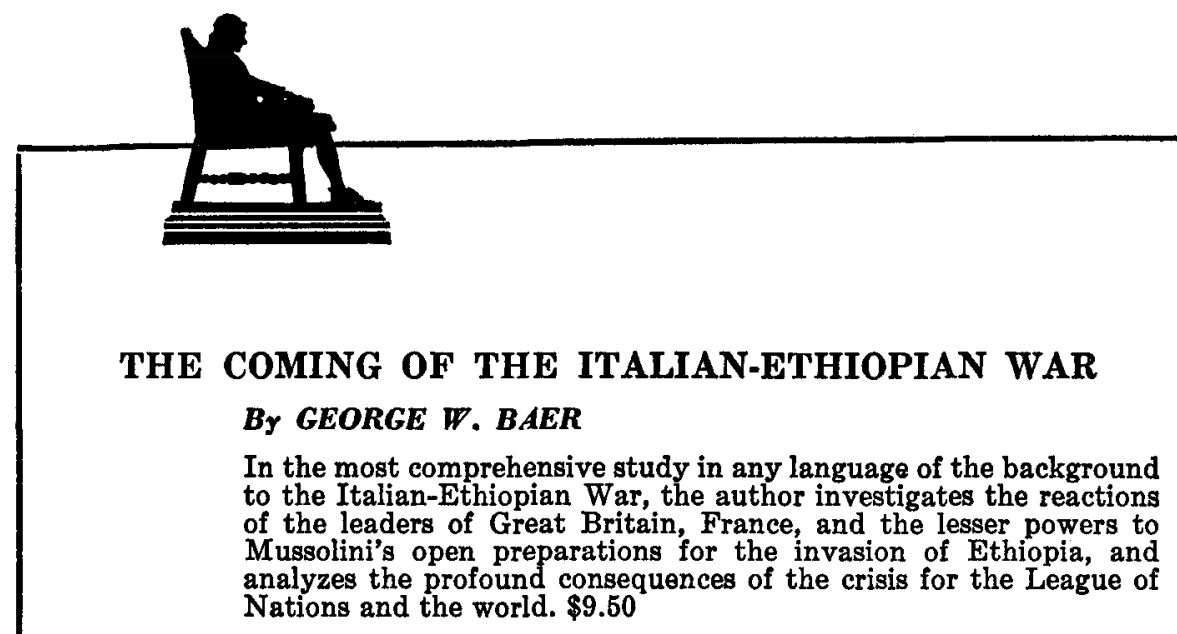

\section{LITERARY DISSENT IN COMMUNIST CHINA}

\section{BY MERLE GOLDMAN}

This examination of the extent of intellectual opposition within Communist China in the 1940's and 1950's analyzes the Party's policies toward the intelligentsia and provides new insights into the nature of totalitarian societies. The author includes accounts of the views, frustrations, and tragic fates of many individual writers. Harvard East Asian Series, 29. $\$ 7.95$

\section{EDMUND BURKE}

The Practical Imagination

BY GERALD W. CHAPMAN

In spite of innumerable assessments, Edmund Burke has remained, in many ways, an elusive and ambiguous figure. Mr. Chapman indicts the many efforts to claim Burke for a variety of ideological fashions and provides an interpretative summary and analysis of Burke's actual thinking on the great issues of his time. $\$ 5.95$

\section{PUBLIC POLICY}

A Yearbook of the Graduate School of Public Administration, Harvard University

Edited by JOHN D. MONTGOMERY and ARTHUR SMITHIES

Volume XIV (1965) in this distinguished series of books contains eighteen essays organized into four parts, entitled "Politics and Foreign Policies," "Problems of Planning," "Policies and Decisions," and "Applications of Federalism." Distributed for the Graduate School of Public Administration. $\$ 7.00$ 
Charles O. Lerche, Jr.

\section{LAST CHANCE IN EUROPE}

Bases for a New American Policy. A clear and cogent analysis of the deterioration of NATO and our relations with our European allies since the end of World War II. Mr. Lerche argues convincingly for a new "partnership." Foreword by Kenneth W. Thompson.

cloth $\$ 5.95$

paper $\$ 2.25$

\section{H. L. Nieburg}

\section{IN THE NAME OF SCIENCE}

A chilling account of the growth of the scientific-military-industrial complex in America. "This copious, astute, opinionated, illuminating, exasperating work should make the nation wonder whether it really wants, after all, to abdicate the future to the Contract State."-Arthur M. Schlesinger, Jr., Life

\section{Belden Paulson, with Athos Ricci}

\section{THE SEARCHERS}

Conflict and Communism in an Italian Town. This excellent casebook in basic, functioning politics is a remarkable study of a village which, because of its past and present, casts a 70 per cent Communist vote. "Sensitive, revealing, important, and thoroughly firstclass ....-Annals

$\$ 6.95$

\section{William L. O'Neill, editor}

\section{ECHOES OF REVOLT}

The Masses, 1911-1917. A bountiful, beautiful anthology from the radical magazine that shocked American manners and morals before it was banned by the U.S. government. "A sumptuous feast . .."-New York Times. "Surprisingly fresh . . The artwork alone is worth the price of admission."-Newsweek. Introduction by Irving Howe. Afterword by Max Eastman.

$\$ 12.95$

QUADRANGLE BOOKS, Inc.

180 North Wacker Drive, Chicago 60606

please mention The AMerican Por.tTical Sctencr Review when writing to advertisers 


\section{GOVERNMENT IN THE UNITED STATES Benjamin Baker / Stanley H. Friedelbaum Rutgers-The State University}

561 pages $\quad 1966 \quad \$ 7.95$

"The genius of America ... [is] to be found in the ways in which an essentially undemocratic constitutional structure has been molded into an effective instrument of popular control and [in] the unusual adaptability of the system as a whole toward meeting the changing requirements of each generation."

This excerpt from the Introduction explains concisely the pervading theme of GOVERNMENT IN THE UNITED STATES, a new introductory text in American government: that our political institutions have changed over the years in response to the needs of American society.

\section{Dther features of GOVERNMET IN THE UNITED STATES have been praised by-}

\section{Donald Robinson, Smith College:}

“l approve of and, in my own courses, share its emphases. It is well-written, and its footnotes give the student good leads for future study-as does the excellent annotated bibliography."

Paul Dolan, University of Delaware:

"Extremely readable and most up-to-date text at the present time. Well organized."

Robert Wood, Augusta College:

“. . . a refreshing approach, an inviting format, a clear process of presentation."

And an Instructor's Manual prepared by Robert S. Getz, Kent State University, is available separately.

For further information, write the regional sales office serving your area.

\section{Houghton Mifflin}

Boston / Atlanta / Dallas / Geneva, III. / New York / Palo Alto 


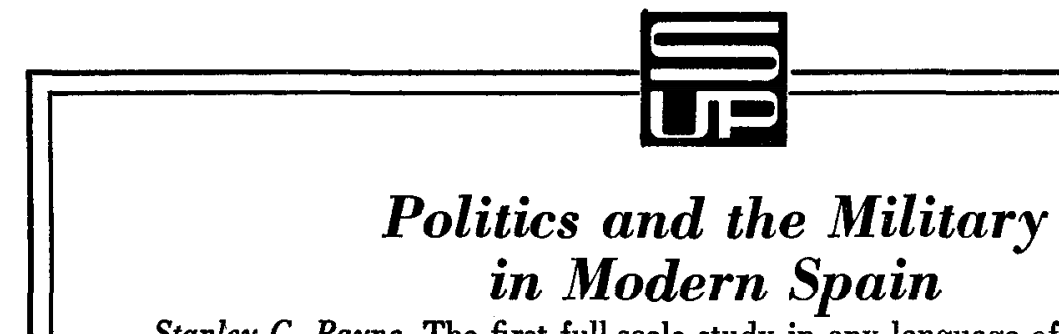

Stanley G. Payne. The first full-scale study in any language of the relation of the military to Spanish politics, government, and public issues in the 19th and 20th centuries. The key period 1917-39 is given special attention. Includes new data on the military conspiracy of 1936 and the Civil War, 1936-39. $\$ 12.50$

\section{West German Foreign Policy 1949-1963}

International Pressure and Domestic Response

Wolfram $F$. Hanrieder. A detailed examination of the pursuit of the three major goals of West German foreign policy-security, political and economic recovery, and reunification-from the beginning of the Federal Republic to the end of the Adenauer regime.

$\$ 7.50$

\section{Tocqueville and the Problem of Democracy}

Marvin Zetterbaum. A fresh study of Tocqueville's well-known "inevitability thesis" that makes possible a new and deeper understanding of his central concern: the problem of reconciling the demands of justice, of equal rights for all men, with the demands of excellence.

$\$ 5.75$

\section{Now in Paperback African Socialism}

Edited by William H. Friedland and Carl G. Rosberg, Jr. "A handy guide to a very diffuse and elusive subject."-The Annals. "An extremely useful study." -The Journal of Politics.

Cloth, $\$ 6.75$; paper, $\$ 2.95$

\section{Marxism in the Modern World}

Edited by Milorad M. Drachkovitch. "An excellent, well-written, and wide ranging introduction admirably suited for the layman and the undergraduate."-The American Political Science Review. Cloth, \$5.95; paper, \$2.95

\section{The British Political System}

André Mathiot. "Historical materials are deftly woven into a tight analytical framework."-The Journal of Politics. "A genuine enrichment of our literature in this field."-World Affairs.

Cloth, $\$ 7.50$; paper, $\$ 2.95$

Order from your bookstore, please

STANFORD UNIVERSITY PRESS 


\title{
INTERNATIONAL POLLTICS IN A REVOLUTIONARY AGE
}

\author{
W. W. KULSKI, Duke University
}

A highly successful text which analyzes the ideological conflicts, discordant national interests and the social and economic factors that underlie today's revolutionary transformations. Close attention is given to the problems of the underdeveloped nations-the "Third World"-and their role in today's power struggle. "Of the perhaps dozen books on the subject that this reviewer has read in the past year, this is by far the most knowledgeable and useful. It can be recommended for student, intellectual and technician alike."-America

650 Pages

\section{THE MAKING OF FOREIGN POLICY: EAST AND WEST}

KURT LONDON, George Washington University

The author scans the policy machinery of the main protagonists of the East-West conflict-United States, Russia, China, Great Britain and France. Special emphasis is given to the vital roles of intelligence and propaganda in the making and implementation of policy, and the agencies and media are carefully defined. 368 Pages

Paperbound

$\$ 1.95$

\section{THE SOVIET ECONOMY SINCE STALIN}

HARRY SCHWARTZ

Russia's current economic difficulties and the reasons for them are analyzed by the New York Times' specialist on Russian affairs. The continuing problem of Soviet agriculture and the ouster of Khrushchev are given close attention.

256 Pages

Paperbound

$\$ 1.95$

\section{LA GUARDIA COMES TO POWER: 1933}

ARTHUR MANN, University of Chicago

A distinguished historian examines the significant elements of the election that was a turning point in the history of American urban politics. "... contains the best account of an urban election we have ever had."-Atlantic Monthly 192 Pages

Paperbound

$\$ 1.95$

\section{THE INTEGRATION OF POLITICAL COMMUNITIES}

KARL W. DEUTSCH, Yale University; PHILIP E. JACOB, HENRY TEUNE, JAMES V. TOSCANO, WILLIAM L. C. WHEATON,

University of Pennsylvania

Integrated political behavior at the metropolitan and international levels is explored in ten essays based on empirical studies in a wide range of fields, including communications, international tensions, planning and regional science, local government, social structure, social psychology and cultural anthropology. 314 Pages

Paperbound

$\$ 1.95$

\section{J. B. LIPPINCOTT COMPANY College Department, East Washington Square, Philadelphia, Pa. 19105}

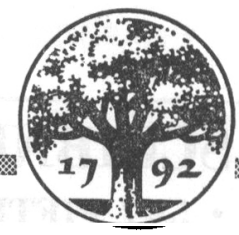

Please mention Thr Axmricay Politicar Screxcr Rrview when writing to advertisers 


\section{ONE MAN, ONE VOTE: \\ WMCA and the Struggle for Equal Representation}

Calvin B. T. Lee. This volume, an ideal text for any course dealing with reapportionment or with constitutional law, gives a detailed "inside" account of one of the six reaportionment cases of 1964. The case, initiated and carried to the Supreme Court by WMCA, a popular radio station in New York City, is documented by newspaper articles and editorials, radio broadcasts, legal briefs, letters, telegrams, court transcripts, and the personal recollections of those involved. The study provides an unusually concrete and fascinating view of the reapportionment problem and also of the way in which the Supreme Court approaches a case, how lawyers prepare and argue their cases, and how decisions are made.

June, 1967. About 200 pages. Paper. $\$ 1.95$

\section{REAPPORTIONMENT}

Edited by Glendon Schubert. In this Scribner Research Anthology the controversial and problematic question of reapportionment is clearly presented and examined from many points of view. More than forty selections provide a lucid and comprehensive view of all aspects of the question-the present situation, the resistance to change, the ways in which legal action is applied to carry out the requirements of the Constitution, and the results of actual reapportionment in certain states. With thirty-three tables to elucidate the questions under discussion, and suggested topics for controlled and library research.

1964. vi, 288 pages. Paper. $\$ 2.95$

\section{CHARLES SCRIBNER'S SONS COLLEGE DEPARTMENT • 597 FIFTH AVENUE - NEW YORK}

Please mention Thi Amrrican Politrcal Screxce Revixw when writing to advertisers 


\title{
RECENT AND FORTHCOMING BOOKS FROM THE PENNSYLVANIA STATE UNIVERSITY PRESS
}

\author{
UNIVERSITY PARK AND LONDON
}

LEGIONS OF BABEL: The International Brigades in the Spanish. Civil War

Verle B. Johnston

Many foreigners who served with the Loyalists have published personal accounts. But whether writing as non-Communists, Communists, or disenchanted ex-Communists, their judgments were seriously clouded by emotions. Here we have the first dispassionate account based on extensive research as. well as correspondence with a number of veterans.

about 180 pages, illustrated, July

$56 \mathrm{~s}$

$\$ 7.50$

SOVIET FOREIGN POLICY, 1928-1934: Documents and Materials

Xenia J. Eudin and Robert M. Slusser

A continuation of Mrs. Eudin's Soviat Russia and the East 1920-1927 (with Robert C. North) and Soviet Russia and the West 1920-1927 (with Harold H. Fisher). In addition to documents, a narrative summary covers the main developments of the period, e.g., Soviet infervention in Manchuria, the growing threat from Japan and Germany, rapprochement with France and Britain, and finally Soviet entry into the League. Special attention has also been paid to Communist policy in Germany on the eve of Hitler's assumption of power.

each volume about 350 pages: 1, March

II (with bibliography and index), August

$71 \mathrm{~s} \quad \$ 9.50$

$71 \mathrm{~s} \quad \$ 9.50$

\section{YUGOSLAVIA'S REVOLUTION OF 1941}

Dragisa N. Ristic

On March 25, 1941, the Yugosiav Government reluctanfly concluded an alliance with the Axis, but two days later air force officers overthrew government and regency, and Hitler immediately ordered Yugoslavia crushed and the attack on Russia postponed. (The author was aide-de-camp to General Simovic, leader of the coup.) It has since been argued that this delay cost Germany the war, but as Ristic demonstrates, the Yugoslar campaign did not delay the altack in the east, and Russian soldiers-not the thermometer-defeated the Wehrmacht. Nevertheless the coup d'etat may indeed have caused Hitler's defeat-but in a much more subtle way than anyone has yet realized.

$56 \mathrm{~s} \quad \$ 7.50$

\section{THE NEW WORLD: 1939-1946}

Richard G. Hewlett and Oscar E. Anderson, Jr.

The first complete account of the scientific discoveries, political maneuvers, and military decisions that produced the alomic bomb. "A work of merit and great importance"-Saturday Reviow. "Impressive and richly documented"-Foreign Affairs. "An honorable and worthy accomplishment"-Scientific American. "Exciting ... impressive ... quite outstanding"-The Economist. "The full history . . . told 10 the very limit of what today's security regulations permit"-Christian Science Monitor. $41 \mathrm{~s} \$ 5.50$

\section{RUSSIA AND THE BALKAN ALLIANCE OF 1912}

\section{Edward C. Thaden}

"Careful work" from a "mass of new source material"-The Economist. "Breaks new ground, and will be indispensable" for "the diplomatic history of the years before the First World War"-Times Lit. erary Supplement

\section{PRESIDENT JAMES BUCHANAN: A BIOGRAPHY}

\section{Philip Shriver Klein}

"Klein has been prodigiously industrious . . . if the general piefure is not alfered, proportions are"Times Literary Supplement.

$71 \mathrm{~s} \$ 9.50$ 


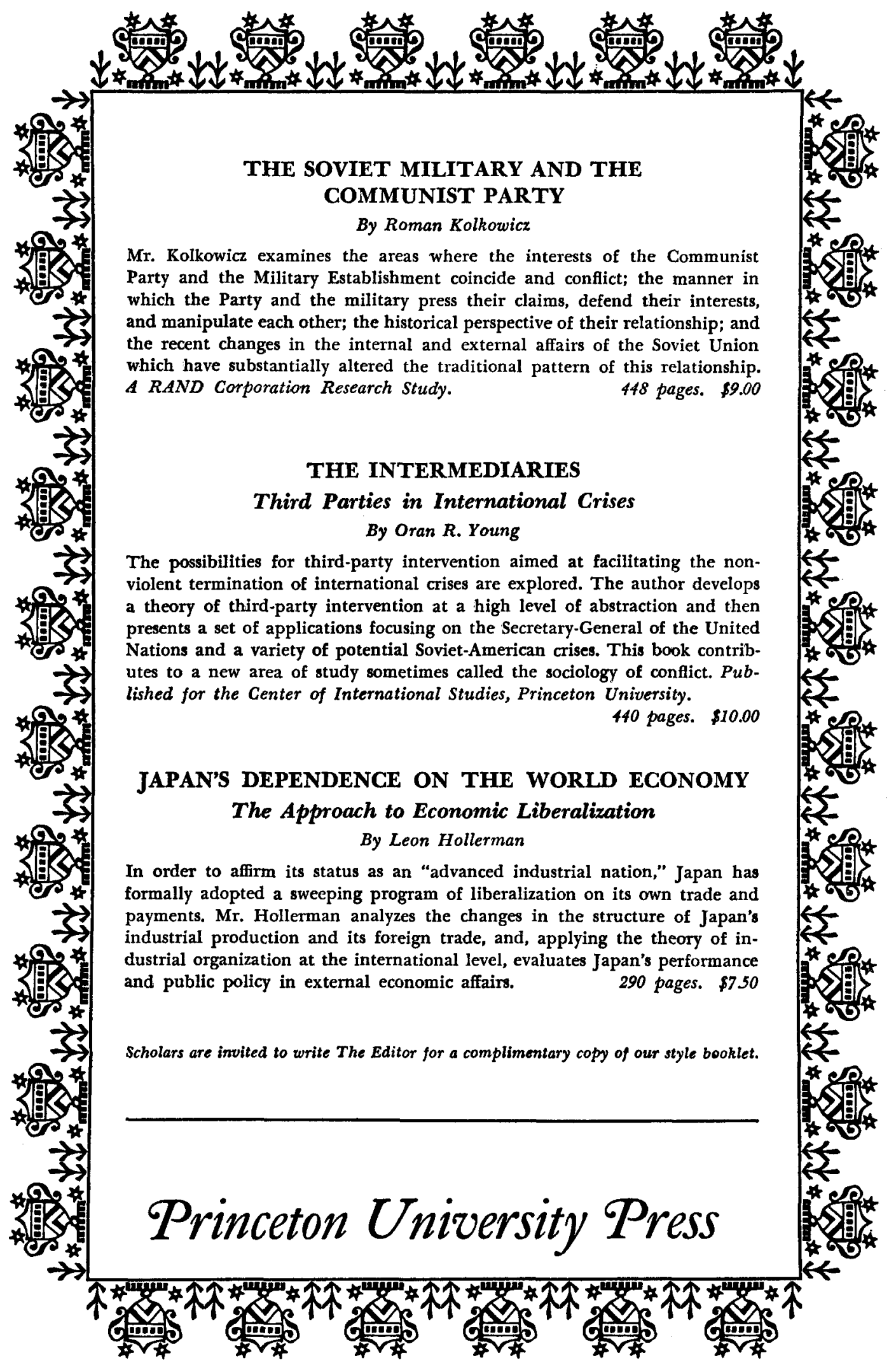

Please mention Thr Ammrican Poxrrical Scruvce Rrvirw when writing to advertisers 


\section{I C K E N S O N}

\section{Theory and Practice of American Democracy}

\section{national, state and local edition}

* (national edition available)

by Fred Krinsky and Gerald Rigby

University of Southern California

March 1967, 500 pp. $\$ 7.95$

*May 1967, 450 pp. $\$ \mathbf{7 . 5 0}$

THEORY AND PRACTICE OF AMERICAN DEMOCRACY is designed as a core text in American Government. The authors assume that these courses should challenge the student with ideas, concepts, and materials from the best available sources. The emphasis is on ideas and concepts, not encyclopedic facts; the student is invited to grapple with dynamics-to understand, not memorize. $7 \%$ × $9 \frac{1}{2}$ hardcover.

American Government in Action

\section{national, state and local}

\section{by Karl M. Schmidt}

Maxwell Graduate School of Citizenship and Public Affalrs, Syracuse University.

This is a book of readings designed to provide a better understanding of the aefual operation of American Government. 502 pp., $6 \times 9$ paperbound. $\$ 3.95$. Cross reference chart available

American National Government in Action. 460 pp., $6 \times 9 . \$ 3.95$

American State and Local Government in Action. 384 pp., $6 \times 9 . \$ 3.95$

\section{California Government Series}

A basic textbook series of seven coordinated paper volumes January 1967, 128 pp., $5 \% 8 x$ $83 \% . \$ 1.95$

George 5. Blair, and Houston 1. Flournoy, LEGISLATIVE BODIES IN CALIFORNIA

James R. Bell, and Thomas J. Ashloy, EXECUTIVES IN CALIFORNIA GOVERNMENT

Beverly B. Cook, THE JUDICIAL PROCESS IN CALIFORNIA

Gerhard N. Rostrold, FINANCING CALIFORNIA GOVERNMENT

Forthcoming titles:

Robert L. Morlan, and Leroy C. Hardy, POLITICS IN CALIFORNIA

John W. Dyckman, ISSUES IN CALIFORNIA DEVELOPMENT

Frank P. Sherwood, and Richard $W$. Gable, CALIFORNIA SYSTEM OF GOVERNMENTS

For approval copies write, Box D-APSR
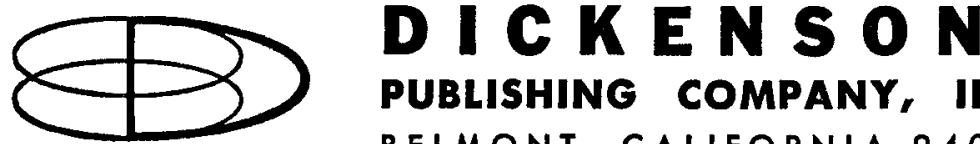

PUBLISHING COMPANY, INC. BELMONT, CALIFORNIA 94002 


\title{
McGRAW-HILL TEXTS IN POLITICAL SCIENCE
}

\section{INTRODUCTION TO POLITICAL SCIENCE,} Second Edition

By CARLTON C. RODEE, TOTTON J. ANDERSON, and CARL Q. CHRISTOL, all of the University of Southern California. 704 pages, $\$ 8.50$

Provides a broad comprehensive introduction to political science as a whole.

\section{STATE AND LOCAL GOVERNMENT,} Second Edition

By CHARLES R. ADRIAN, University of California, Riverside. McGraw-Hill Series in Political Science. 608 pages, $\$ 8.50$

Emphasizes the vital role of state and local government in American political life.

\section{VOICE OF THE PEOPLE, Second Edition}

Edited by REO M. CHRISTENSON, Miami University; and ROBERT O. McWLLIAMS, Eastern Michigan University. McGraw-Hill Series in Political Science. 640 pages, $\$ 7.95$ (cloth edition); $\$ 5.95$ (softcover).

A collection of readings on public opinion and propaganda.

\section{FOUNDATIONS OF AMERICAN GOVERNMENT} AND POLITICAL SCIENCE SERIES

JOSEPH P. HARRIS, Consulting Editor. Each volume: $\$ 3.75$ (cloth edition); $\$ 1.60$ (soft-cover).

Volumes in the Series:

Charles R. Adrian: Governing Our Fifty States and Their Commumities, Second Edition

Hugh A. Bone and Austin Ranney: Politics and Voters, Second Edition

John J. Corson and Joseph P. Harris: Public Administration in Modern Society

Rowland Egger: The President of the United States. Available Fall

Andrew Hacker: The Study of Politics
Joseph P. Harris: CONGRESS and the Legislative Process. Available Fall

Charles O. Lerche: America in World Affairs, Second Edition

C. Herman Pritchett: The American Constitutional System, Second Edition

H. Frank Way: Liberty in the Balance, Second Edition

\section{CONTEMPORARY POLITICAL SCIENCE:} TOWARD EMPIRICAL THEORY

ITHIEL POOL, Massachusetts Institute of Technology, Editor. McGraw-Hill Series in Political Science. Available late Summer

Consists of a set of the main Plenary Session papers delivered at the 1966 Convention of the American Political Science Association.

THE GOVERNMENT AND POLITICS OF CALIFORNIA, Third Edition

By HENRY A. TURNER, University of California, Santa Barbara; and JOHN A. VIEG, Pomona College and Claremont Graduate School. 304 pages, \$5.95 (cloth); $\$ 3.75$ (soft-cover).

Provides accurate, comprehensive, and yet concise coverage of all significant aspects of California state and local government.

THE AMERICAN SYSTEM OF GOVERNMENT, Ninth Edition

Available Spring

THE AMERICAN FEDERAL GOVERNMENT, Ninth Edition.

Available Spring

By JOHN H. FERGUSON, The Pennsylvania State University; and DEAN E. MCHENRY, University of California at Santa Cruz.

THE AMERICAN SYSTEM OF GOVERNMENT covers the entire range of government-national, state, and local. THE AMERICAN FEDERAL GOVERNMENT is exactly the same except that it omits the concluding chapters which deal with state and local governments.

\section{MEGRAW-HILL BOOK COMPANY}

\author{
330 West 42nd Street \\ New York, New York 10036
}

Please mention The American Political Science Review when weriting to advertisers 


\section{New and recent titles from Ronald}

\section{GOVERNMENT IN THE UNITED STATES}

Webb S. Fiser, State University of New York at Albany; Stuart Gerry Brown, University of Hawaii; and John S. Gibson, Tufts University

Just Published-This textbook surveys concisely but comprehensively the framework of the American governmental system. Intergovernmental relations are developed as cooperative action between levels of government rather than as compartmentalized treatments of federal, state and local systems. Going beyond discussion of politics, parties, and pressure groups, this book shows how the political process unfolds around concrete policy issues in the context of changing historical developments. Particular attention is given to such currently important problems as urban renewa1, metropolitan areas, poverty, race relations, law enforcement, agriculture, and education. The chapter on science and government and those on the international scene create a sense of student involvement in America's place in the world order. 1967. $803 \mathrm{pp}$.

\section{INTERNATIONAL ORGANIZATION}

Donald C. Blaisdell, The City College of The City University of New York

This textbook acquaints the student with the theory and practice of international organization. It also serves to identify problems in international organization and to open fresh paths for further inquiry. The governmental structures that the world's nation-states have agreed to establish, their procedures, staffs, and finances are examined together with methods for meeting threats or breaches of the peace. Analyzes the success of these organizations in maintaining peace, promoting respect for human rights, and fundamental freedoms, and dealing with problems of general welfare. Questions at the end of each chapter. 1966. $531 \mathrm{pp}$. $\$ 7.50$

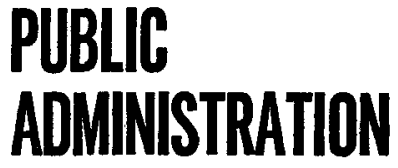

John M. Pfiffner, University of Southern California; and Robert Presthus, York University, Toronto

Just Published-This famous textbook examines administration at all levels of government. It integrates descriptive-institutional materials of administrative science with behavioral analyses of administration in action. It analyzes such aspects as the historical and institutional framework, separation of powers, role of executives (particularly that of the modern specialist), and the problem of obtaining superior talent. Covers decision-making and the data-processing revolution, and incorporates recent research into group behavior, individual motivation, and leadership dynamics. 5th $E d$., 1967. 567 pp.

$\$ 8.00$

\section{STATE AND LOCAL GOVERNMENT AND ADMINISTRATION}

Russell M. Ross, University of Iowa; and Kenneth F. Millsap, Assistant City Manager, Iowa City, Iowa

This text provides a thorough treatment of the governmental activities of the 50 states and their local governmental units. Although predominant emphasis is on administrative aspects of state and local government, the book also presents material on the structure of governmental units below the national level. The role of counties, the position of the municipalities and special districts, and the peculiar problems of metropolitan areas are examined in detail. The importance of intergovernmental coordination is stressed, as is the growing relationship between the national and local governments. 1966. 705 pp., illus.

\section{The Ronald Press Company}

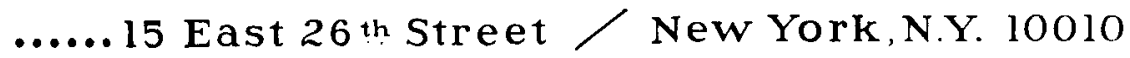

Please mention The Ambrican Political. Scrence Review when writing to advertisers 


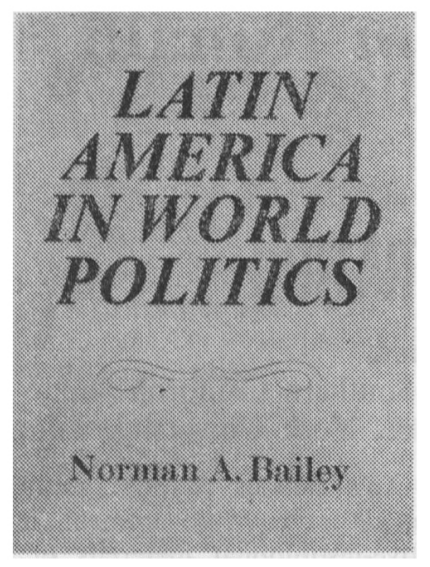

\title{
LATIN AMERICA IN WORLD POLITICS
}

\author{
by NORMAN A. BAILEY \\ Preface by RONALD SCHNEIDER \\ Latin America Institute of Columbia University
}

As an area of shifting political alliance in the "backyard" of the United States, Latin America holds a particularly significant place in world politics today. The international repercussions of the 1959 revolution in Cuba served as a violent reminder of this fact, and yet, there is a conspicuous gap in the literature on this aspect of Latin American affairs.

In his comprehensive treatment of the subject, Professor Bailey has set out to fill this gap and provide the student and informed general reader with an understanding of the role of Latin America in the international power structure. Working from an overview of the setting of world politics and the domestic situation of Latin America, he demonstrates the political challenges that arise from their interaction and proceeds to analyze the various ways in which the Latin American Nations have tried to meet these challenges through law, association and union.

Norman Bailey is Associate Professor of Political Science and Chairman of Latin American Studies, Queens College of the City University of New York.

"The frankest treatment of the subject since John Normanno's classic study published in 1930 ... provocative and refreshing."-Hobart A Spalding, Jr., History Department, Brooklyn College

Index, Maps, Charts, Chapter Bibliographies, 320 pages $\$ 7.50$

\section{THE DILEMMAS OF AFRICAN INDEPENDENCE}

\section{by L. GRAY COWAN}

In this important book, originally published in 1964 and now reissued in a completely updated edition, Dr. Cowan, director of Columbia University's Program of Studies on Africa, discusses the many problems which confront modern Africa: the emergence of single-party governments; the growing tensions between civilian and military leaders; the scarcity of trained personnel; the numerous obstacles to economic cooperation; and many others.

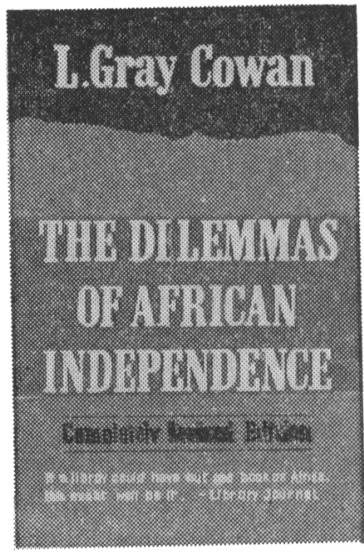

"If a library could have but one book on Africa, this might well be it."-Library Journal

"This is a perceptive and provocative study."-New York Times 


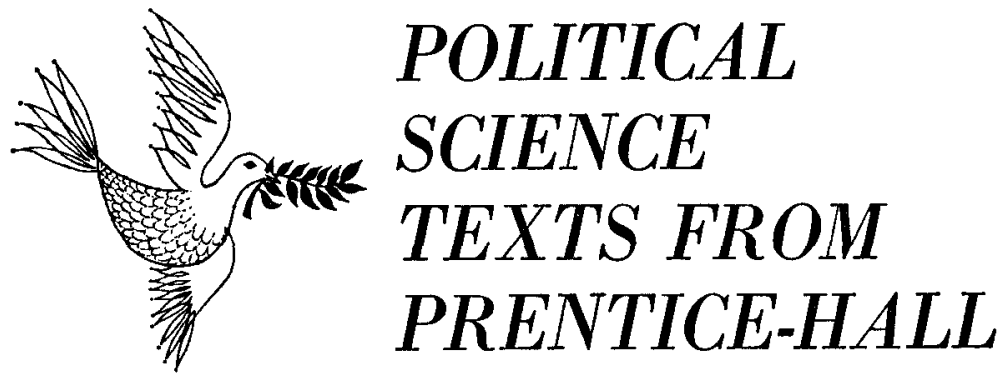

THE GOVERNMENT OF THE UNITED STATES, by Ernest B. Fincher, Montclair State College By using factual information and anecdotal material the author underscores the dynamic character of American government and its relationship to the lives of ordinary citizens. January 1967, 320 pp., $\$ 3.95$

INTERNATIONAL POLITICS, by K. J. Holsti, University of British Columbia. Offers an integrated framework for analyzing the behavior of states, with emphasis on the systemic and domestic sources of external political goals, the bargaining methods used to achieve or defend objectives and interests, restraints on policies, and behavior and procedures conducive to the resolution of international conflicts. May 1967, 512 pp., $\$ 8.95$
PARTIES AND THE GOVERNMENTAL SYSTEM: A BOOK OF READINGS, by Garold W. Thumm, Bates College and Edward Janosik, University of Pennsylvania. Composed of articles from scholarly journals and excerpts from important political science books, this anthology brings together selected materials dealing with the theory and practice of political parties. May 1967, 320 pp., $\$ 3.95$

FUNCTION AND POLICIES OF AMERICAN GOVERNMENT, 3rd Edition, 1967, by J. W. Peltason, University of California, Irvine, and James M. Burns, Williams College. This text describes comprehensively what American government does and what its specific policies are. It discusses governmental policies, functions, and programs against a background of history and politics. May 1967, 448 pp., $\$ 6.95$

AMERICA'S ROLE IN WORLD AFFAIRS, edited by Dankwart A. Rustow, Columbia University. All volumes in this series are approx. $128 \mathrm{pp}$. each. paper $\$ 1.95$, cloth $\$ 4.50$

AFRICA AND UNITED STATES POLICY, by Rupert Emerson, Harvard University. April 1967
FOREIGN AID IN INTERNATIONAL POLITICS, by John D. Montgomery, Harvard University. January 1967

\section{For Future Publication:}

THE BURDEN OF DECISION: AMERICAN FOREIGN POLICY SINCE 1945, by Charles Burton Marshall, The Johns Hopkins University

LATIN AMERICA AND UNITED STATES POLICY, by Kalman H. Silvert, Dartmouth University

THE MAKING OF UNITED STATES FOREIGN POLICY, by William C. Olson, Columbia University

THE WEB OF INTERDEPENDENCE: THE UNITED STATES AND INTERNATIONAL ORGANIZATIONS, by Ernst B. Haas, University of California, Berkeley
ASIA AND UNITED STATES POLICY, by Wayne A. Wilcox, Columbia University

COLD WAR AND COEXISTENCE: RUSSIA, CHINA AND THE UNITED STATES, by William E. Griffith, Massachusetts Institute of Technology

EUROPE AND UNITED STATES POLICY, by Stanley Hoffman, Harvard University

MILITARY STRATEGY IN WORLD POLITICS, by Walter Goldstein, Brooklyn College

THE NEW SETTING OF WORLD POLITICS, by Dankwart A. Rustow, Columbia University 


\title{
$\mathcal{N}_{\text {ew }}$ and $\mathcal{R}_{\text {ecent }}$ PUBLICATIONS from PERGAMON
}

ASPECTS OF BRITISH POLITICS 1904-1919

D. Collins, University of Leeds

Deals with the changes in foreign policy brought about by the War and Britain's relative loss of power at the beginning of the twentieth century.

1966 372 pages

Flexi-covered, $\$ 5.00$

\section{BRITISH POLITICS 1918-1964}

L. J. Macfarlane, Oxford University

An account of the main political events in British history from 1918-1964, covering both domestic and foreign policy.

1965

$$
184 \text { pages }
$$

Flexi-covered, $\$ 2.95$

THE INDIAN UNION AND THE STATE

A. Krishnaswami, Supreme Court of India

The federal system of government that followed British rule in India has, until recently, tended to increase the power of the central government at the expense of the states. Dr. Krishnaswami presents the case for restoring the position of the Provinces to insure the growth of a healthy cooperative federalism and explains some of the measures that have already been taken in this direction.

1965

100 pages

Flexi-covered, $\$ 2.95$

\section{ONE FROM SEVEN HUNDRED}

A Year in the Life of Parliament

William Norris, Parliamentary Correspondent of The Times

Mr. Norris offers a lively and perceptive account of the events, procedures and personalities in Parliament in the first year of Mr. Wilson's Labour government.

1966

131 pages

Flexi-covered, $\$ 1.95$

\section{PLANNING IN THE SOVIET UNION}

\author{
Philippe J. Bernard
}

The author reviews Soviet economic planning with particular attention to the last decade, describing the characteristics of the Soviet system, the significance of ideology, the coordination of planning, and the problems of management.
1966 336 pages

Flexi-covered, $\$ 9.50$

\section{PRIVATE ENTERPRISE IN DEVELOPING COUNTRIES}

\section{W. M. Clarke, Editor of The Banker}

A lucid discussion of the need for private enterprise to complement government aid in the developing countries.

1966

69 pages

Flexi-covered, $\$ 1.50$

\section{SCIENCE, TECHNOLOGY AND COMMUNISM}

Some Questions of Development

1. G. Kurakov

The author is concerned with the relation of scientifio research to industrial growth and productivity in the Soviet Union.

1967

136 pages

$\$ 6.00$

THE UNITED NATIONS AND WORLD REALITIES

M.J. Lee, University of Southampton

An appraisal of the United Nations, its successes, failures, opportunities, and challenges.

1966

255 pages

Flexi-covered, $\$ 3.95$

\section{WESTMINSTER WORKSHOP}

A Student's Guide to the British Constitution

R. K. Mosley

An examination of how the British constitution works today. Each chapter contains a section of discussion points, questions for review, examination questions, and a bibliography for further reading.

1965

206 pages

Flexi-covered, $\$ 2.95$

To examine copies on approval, write to:

College Division

Box 901

PERGAMON PRESS

44-01 21st Street

Long Island City, New York 11101 


\section{You mean I can get $\$ 50,000$ of TIAA Life insurance for less than $\$ 100$ ?}

That's what an Assistant Professor asked us when he heard about TIAA's low life insurance costs.

It's true. At his age 30 the annual premium for a 20-Year Home Protection policy providing $\$ 50,000$ initial amount of insurance is $\$ 159.00$. The first year dividend, based on our current dividend scale, is $\$ 61.00$, making a net payment of $\$ 98.00$. Dividends, of course, are not guaranteed.

The Home Protection plan is level premium Term insurance providing its largest amount of protection initially, reducing by schedule each year to recognize decreasing insurance needs. This is just one example of the many lost-cost TIAA plans available. If you need more protection for your family, ask us to mail you a personal illustration with figures for a policy issued at your age. We'll also send the Life Insurance Guide describing other TIAA policies.

ARE YOU ELIGIBLE FOR TIAA?

Yes, if you are employed by a college, university, private school or other nonprofit educational or scientific institution that qualifies for TIAA eligibility.
TEACHERS INSURANCE AND ANNUITY ASSOCIATION 730 Third Avenue, New York, N. Y. 10017

Please mail the new Life Insurance Guide and a personal illustration.

$\begin{array}{ll} & \text { Your } \\ \text { Name_Date of Birth } & \text { Date }\end{array}$

Address ZIP

Dependents' Ages

Nonprofit Employer.

college, university, or other educational or scientific institution 


\section{New States of States}

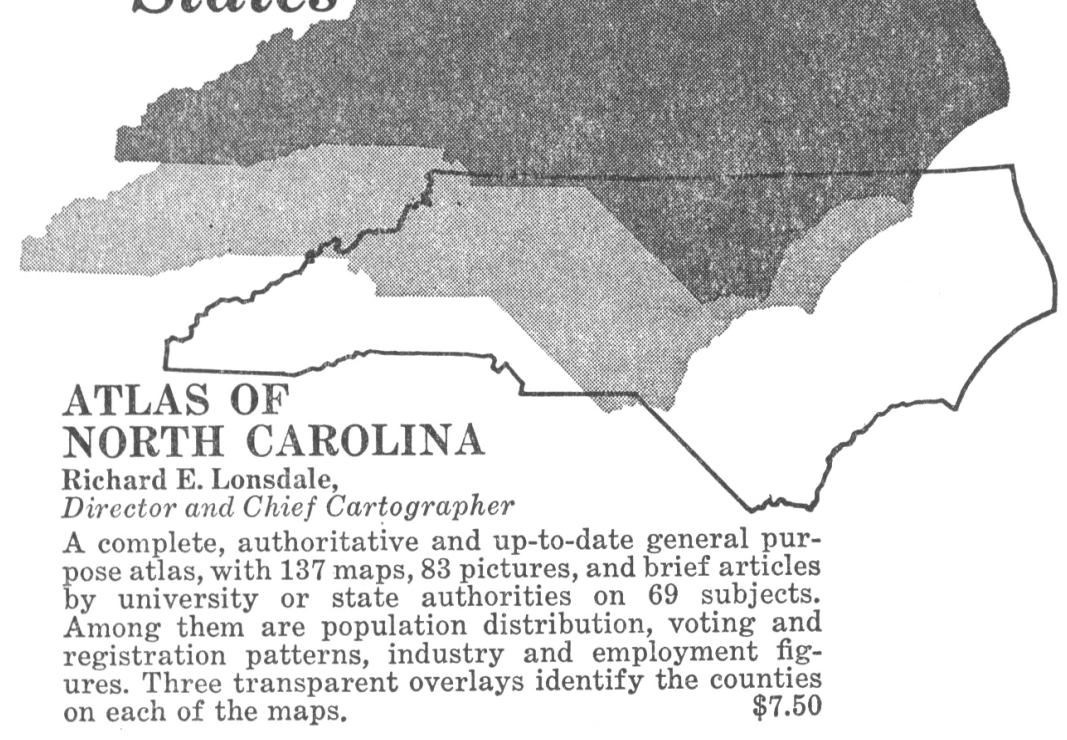

\section{INTERSTATE}

\section{COMPACTS IN THE POLITICAL PROCESS \\ by Weldon V. Barton}

In case studies of fifteen agencies, this book describes the uses and limitations of compacts in coping with regional problems in the American federal system. Emphasis is on evaluation of regulatory, metropolitan area, river basin and state service compacts in political contexts.

$\$ 5.00$

\section{BRAZILIAN PLANNING}

\section{Development Politics and Administration}

by Robert T. Daland

This analysis of the complex Brazilian political system during the period from 1945 to 1965 is an outstanding case study of the nature and effectiveness of national planning in a developing country.

$\$ 6.00$

\section{At your bookstore or}




\section{INDEX TO ADVERTISERS}

Appleton-Century-Crofts, Inc. 603

University of Chicago Press $593,594,595$

Columbia University Press $581,584,585$

Cornell University Press 590,591

Dickenson Publishing Company . . . . . . . . . . . . . . . . . 617

Dorsey Press .................................. 597

Exposition Press ............................. 598

Harper \& Row . . . . . . . . . . . . . . . . . . . . . . 313

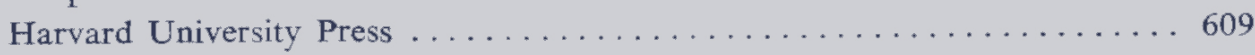

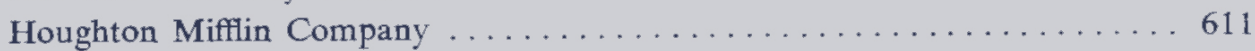

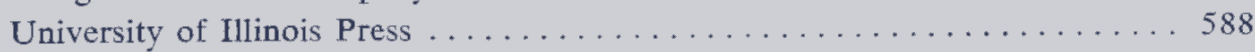

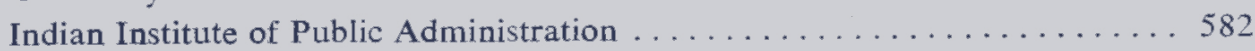

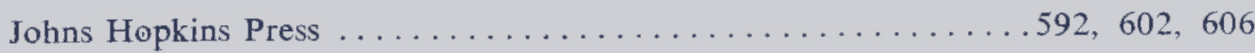

Journal of Constitutional and Parliamentary Studies . . . . . . . . . 583

J. B. Lippincott Company . . . . . . . . . . . . . . . . . 613

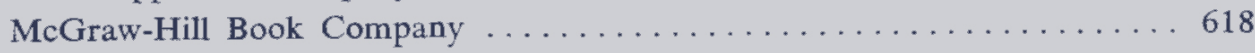

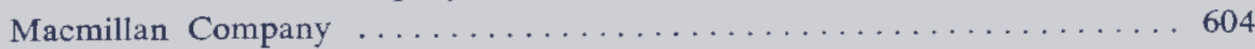

University of North Carolina Press . . . . . . . . . . . . . . . 624

Northwestern University Press . . . . . . . . . . . . . . . . . . . 607

Oxford University Press $\ldots \ldots \ldots \ldots \ldots \ldots \ldots \ldots \ldots \ldots \ldots \ldots, 600,601$

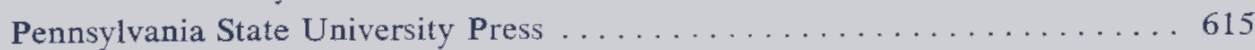

Pergamon Press, Inc. . . . . . . . . . . . . . . . . . . 622

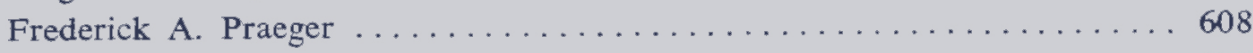

Prentice-Hall, Inc. . . . . . . . . . . . . . . . . . . . . 621

Princeton University Press $\ldots \ldots \ldots \ldots \ldots \ldots \ldots \ldots \ldots \ldots$ Cover II, 616

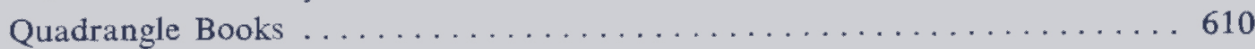

Rand McNally \& Company . . . . . . . . . . . . . . . . Cover IV

Ronald Press Company ............................ 619

St. Martin's Press . . . . . . . . . . . . . . . . . . . . . . 589

Science Research Associates . . . . . . . . . . . . . . . . 592, 598

Scott, Foresman \& Company . . . . . . . . . . . . . . . . . . . 605

Charles Scribner's Sons . . . . . . . . . . . . . . . . . . . 614

Stanford University Press . . . . . . . . . . . . . . . . . . . 612

Teachers Insurance \& Annuity Association . . . . . . . . . . . . . . . 623

D. Van Nostrand Company, Inc. . . . . . . . . . . . . . . . 596

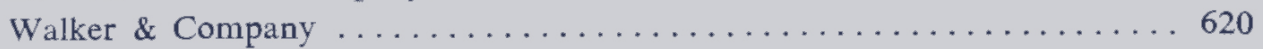

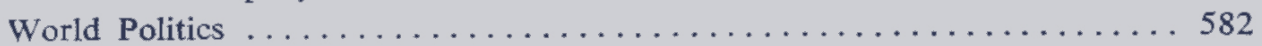

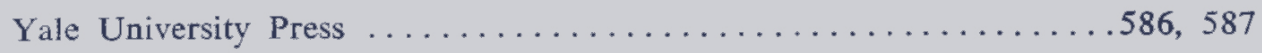


organlzation sciences

Observed behavior... practice... theory ... statistical tools ... structural models of new relationships...

All essential to a complete overview of the problems within organizations.

For effective presentation of this multi-disciplinary information, look for Rand McNally books in the organization sciences.

\section{RAND MCNALLY SERIESIN THE ORGANIZATION SCIENGES}

Edited by ROBERT T. GOLEMBIEWSKI, University of Georgia

This series of paperbound books analyzes the structure, function, and personnel of organizations by using information and methodological resources of the social scierices. Developed in detail in a variety of areas, the series is designed so that teachers, researchers, and practitioners will find the material equally useful. The separate but complementary volumes offer maximum flexibility: the books may be used in any sequence and with any combination of basic and supplementary materiais.

\section{EMPATHY AND IDEOLOGY:}

\section{Aspects of Administrative Innovation}

Edited by CHARLES PRESS, Michigan State University ALAN ARIAN, Tel Aviv University 1967 - 286 pages - $\$ 3.50$ paper

Twelve original essays by authorities in communications theory, group dynamics, sociology, and psychology deal with the kinds of knowledge essential to administrative innovation.

\section{ORGANIZING MEN AND POWER:}

\section{Patterns of Behavior and Line-Staff Models}

ROBERT T. GOLEMBIEWSKI, University of Georgia 1967 - 288 pages $\quad \$ 3.50$ paper

Drawing on both practical operations and current research, the author forms the colleague concept of staff"-an unorthodox model of line-staff relationships which challenges traditional theory.

\section{THE PROFESSIONAL IN THE ORGANIZATION}

MARK ABRAHAMSON, Illinois Institute of Technology 1967

Unlike past studies in the field, this book does not merely deal with the individual, but rather studies the professional person in such organizational contexts as medicine, law, and scientific research and analyzes the common role of the professional in each case.

MANAGERIAL BEHAVIOR AND ORGANIZATION DEMANDS: Management as a Linking of Levels of Interaction

Edited by ROBERT T. GOLEMBIEWSKI, University of Georgia FRANK K. GIBSON, University of Georgia 1967

Thirty managerially-related articles are organized to focus on a general overview of organization theory, management of individuals and groups, and administration of large organizations. 